\title{
Kur'ân Hıfzı Hakkında İki Mesele: Hâfızların Şefaat Hakkı ve Hâfızlığın Unutulmasının Vebali
}

\section{Two Issues That Related to the Memorisation of The Qur'an: The Intercession Right of the Hafiz and the Sin of Forgetting the Memorisation of the Qur'an}

\author{
Abdulvehhab GÖZÜN \\ Dr. Öğr. Üyesi, Gümüşhane Üniversitesi, Illahiyat Fakültesi, Hadis Anabilim Dalı \\ Assistant Professor, Gümüşhane University, Faculty of Theology, Department of Hadith \\ Gümüşhane, Turkey \\ abdulvehhab.gozun@gumushane.edu.tr \\ orcıd.org/0000-0003-0333-4463
}

\author{
Makale Bilgisi / Article Information \\ Makale Türü / Article Types \\ : Araştırma Makalesi / Research Article \\ Geliş Tarihi / Received \\ : 01 Ekim / October 2020 \\ Kabul Tarihi / Accepted \\ : 15 Ekim / October 2020 \\ Yayın Tarihi / Published \\ :15 Aralık / December 2020 \\ Yayın Sezonu / Pub Date Season : Aralık / December \\ Cilt / Volume: 7 - Sayı / Issue: 2 - Sayfa / Pages: 421-447
}

Atıf / Cite as

Gözün, Abdulvehhab. "Kur'ân Hıfzı Hakkında İki Mesele: Hâfızların Şefaat Hakkı ve Hâfızlığın Unutulmasının Vebali”. Bülent Ecevit Üniversitesi Ilahiyat Fakültesi Dergisi 7/2 (2020), 421-447.

Doi: $10.33460 /$ beuifd. 803500

İntihal / Plagiarism

Bu makale, en az iki hakem tarafından incelendi ve intihal içermediği teyit edildi.

This article has been reviewed by at least two referees and scanned via a plagiarism software.

Yayın Hakkı / Copyright ${ }^{\circ}$

Zonguldak Bülent Ecevit Üniversitesi, İlahiyat Fakültesi tarafından yayınlanmıştır. Tüm hakları saklıdır.

Published by Zonguldak Bulent Ecevit University, Faculty of Theology, Zonguldak, Turkey. All rights reserved.

Öz: Allah'ın (c.c.) insanlara doğru yolu göstermek için yeryüzüne indirdiği kitapların sonuncusu ve en kapsamlısı olan Kur'an'ın anlaşılması ve yaşanması asıl hedef olmakla beraber, ezberlenmesi de hiç şüphesiz üstün bir değerdir. Aynı zamanda ilk hâfız olan Hz. Peygamber'den (s.a.v.) itibaren tarih boyunca her nesilde bu fazileti idrak eden nice müslüman olmuştur. Günümüze bakıldığında da hem ülkemizde hem de diğer İslâm beldelerinde durumun aynı şekilde devam ettiği görülmektedir.

Kur'an hâfızlığının bu denli yaygın ve özen gösterilen bir mesele olmasını sağlayan birçok faktör vardır. Bunlardan biri de hâfızlıkla ilgili Hz. Peygamber'den (s.a.v.) vârid olan birtakım hadis rivayetleridir. Tespit edebildiğimiz kadarıyla bunlardan bir kısmı hâfızlığın faziletine dair olup diğer bir kısmı da hâfızlığın unutulmasının vebaliyle ilgilidir. Birinci grup rivayetler Kur'an'ın ezberlenmesine teşvik ederken; ikinci grupta olanlar ezberlendikten sonra unutulmasının tehlikesine işaret etmektedir. Ancak amellerin fazileti ile ilgili sahih rivayetlerin yanı sıra bazı aşırı zayıf yahut uydurma rivayetler 
olduğu gibi Kur'an hâfızlığına dair de birtakım sahih rivayetlerle birlikte aşırı zayıf yahut uydurma rivayetler bulunmaktadır. Bu rivayetlerin değerlendirilip incelenmesi, hâfızlığa dair Hz. Peygamber'in (s.a.v.) yaklaşımının ortaya çıkarılması açısından önemlidir.

Binâenaleyh bu çalışmada toplumun belli bir kesimi tarafından yaygın olarak dile getirilen hâfızların âhirette yakınlarından yetmiş kişiye şefaat edeceklerine ve hâfızlığını unutan kişilerin bazı cezalara maruz kalacağına dair rivayetler sened ve metin tenkidi bağlamında ele alınıp incelenecektir. Böylece insanlara bu konuda doğru bilgi verilmesi amaçlanmaktadır. Sonuç olarak da her faziletli amelde olduğu gibi bu meselede de itimat ve ihticâc edilebilecek rivayetlerin nazar-ı dikkate alınmasının önemine işaret edilecektir.

Anahtar Kelimeler: Hadis, Hâfız, Hâfızlık, Şefaat, Unutmak, Vebal.

Abstract: The Quran is the last and the most comprehensive book that Allah the Almighty sent down to the earth to show people the right way. Understanding and practising the Qur'an are the main goals. But, undoubtedly, memorising it is an outstanding value. Many Muslims that perceives this virtue have memorised the Qur'an from generation to generation since the Prophet (PBUH), who was the first hâfiz that has memorised the Qur'an. Looking at the present day, it is seen that the situation has been continued in the same way both in our country and in other Islamic towns as well.

One of the many factors that make memorising the Qur'an to be such a widespread and important matter is some of the hadith narrations, which are said to be from the Prophet (PBUH). As far as it can be determined, some of the hadith narrations are about the virtue of memorising the Qur'an, while others are the sin of forgetting the Qur'an after memorising it. The first group of hadith narrations encourage people to memorise the Qur'an, While in the second group of hadith narrations point out the danger of forgetting the Qur'an after memorising it. However, besides the authentic hadith narrations about many virtuous deeds, there are some extremely weak and fabricated narrations as well, about the memorising the Qur'an

Therefore, in this study, the hadith narrations will be analysed in the context of the script and the text criticism which are commonly expressed among certain segments of the society that concerns the hâfizes who will intercede seventy people from their relatives in the hereafter and those will be subjected to a great torment in the Hellfire who forgets the Qur'an after memorising it. As a result, it will be pointed out the importance of taking into account the hadith narrations that can be shown as reliable and adducible evidence in this matter, as in every virtuous deed.

Keywords: Hadith, Hâfız, Hâfızness, Intercession, Forgetting, Sin. 


\section{Giriş}

Bazı âyetlerde de açıkça ifade edildiği gibi ${ }^{1}$ Kur'an-ı Kerîm, Hz. Peygamber'e (s.a.v.) toplu bir şekilde değil risâlet yıllarına yayılmış olarak parça parça indirilmiştir. Bu sebeple de onun hem Hz. Peygamber (s.a.v.) hem de ashâbı tarafından ezberlenmesi peyderpey olmuştur. Dolayısıyla asr-ı saâdette $\mathrm{Hz}$. Peygamber'le (s.a.v.) birlikte baştan sona bütünüyle Kur'an'ı ezberleyen sahâbî sayısı tabiatıyla az olmuştur. Bunların kaç kişi oldukları hakkında farklı görüşler bulunmaktadır. ${ }^{2}$

Ancak en azından namaz kılabilecek kadar Kur'an'dan bazı âyetleri yahut bazı sûreleri her sahâbînin ezbere bildiğini söylemek mümkündür. Ayrıca bazıları diğerlerine göre şüphesiz daha çok sûre yahut âyet ezbere bilmekteydi. Özellikle aralarında "kurrâ" denilen kişilerin varlığı bunu açıcça göstermektedir. Hz. Peygamber'den (s.a.v.) sonra ise Kur'an ezberini tamamlayan sahâbîler başta olmak üzere İslâm tarihi boyunca hâfızların sayısı artmaya başlamış ve günümüze dek böyle devam etmiştir. ${ }^{3}$

Yaşadığımız çağda da durum aynıdır. Hatta günümüzün iletişim ve ulaşım imkânlarından istifade edilerek hâfızlık eğitiminde farklı metodlar ${ }^{4}$ ortaya konulmuş, böylece dünya üzerindeki Kur'an hâfızlarının sayısı daha da artmıştır. Ülkemiz de şüphesiz buna dahildir. Hâfızlığın bu kadar ilgi odağı olmasının sebeplerinin başında elbette ki Kur'an'ın son ve en büyük semâvî kitap olması gelmektedir. Ancak bunun yanı sıra başka nedenlerin varlığı da söz konusudur.

Bu konudaki manevî sâiklerden biri de hâfızlığın faziletine dâir $\mathrm{Hz}$. Peygamber'den (s.a.v.) nakledilen birtakım hadislerdir. ${ }^{5} \mathrm{Bu}$ tür rivayetler, hadis kitaplarının daha çok "Fezâilü'l-Kur'ân" başlıkları altında yahut bu ve benzeri isimlerle müstakil olarak yazılmış birtakım kitaplarda yer almaktadır. ${ }^{6}$

Günümüzde icazet merasimleri başta olmak üzere çeşitli platformlarda insanları Kur'an'ı ezberlemeye teşvik etmek gayesiyle bu tür rivayetler sıkça

el-İsrâ 17/106; el-Furkân 25/32.

2 bk. Ökkeş Dağ, Hz. Peygamber Zamanında Kur'an'ın Ezberlenmesi ve Hafız Sahabiler (Ankara: Ankara Üniversitesi, Sosyal Bilimler Enstitüsü, Yüksek Lisans Tezi, 2006), 50-76.

3 Hafızığın tarihî serüvenine genel bir bakış için bk. Hatice Şahin, "Başlangıcından Günümüze Kadar İslam Coğrafyasında Hafızlık Tedrisatı", Dinbilimleri Akademik Araștırma Dergisi 11/2 (2011), 199-220.

4 Bu yöntemler için bk. Ömer Özbek, "Dünyada Hafızlık Yöntem Örnekleri”, Bilimname, 29/2 (2015), 183-209.

5 Bu tür rivayetlerle ilgili genel birtakım değerlendirmeler için bk. Mesut Çakır - Yavuz Horoz, "Hafızlığı Teşvik Eden Hadisler Üzerine Genel Bir Değerlendirme", Kafkas Üniversitesi Illahiyat Fakültesi Dergisi 5/9 (2018), 118-140.

6 Bu tür eserlerden bazıları şunlardır: Ebû Ubeyd el-Kâsım b. Sellâm b. Abdillah el-Herevî el-Bağdâdî, Fedâilü'lKur'ân, thk. Mervân el-Atıyye vd. (Dımaşk: Dâru Ibn Kesîr, 1415/1995), 41-106; Ebû Abdillah Muhammed b. Eyyûb b. Yahyâ b. ed-Düreys el-Becelî er-Râzî, Fedâilü'I-Kur'ân, thk. Gazve Büdeyr (Dımaşk: Dâru'l-Fikr, 1408/1987), 3940, 55-65, 76-78; Ebû Bekr Ca'fer b. Muhammed b. el-Hasan b. el-Müstefâd el-Firyâbî, Fedâilü'l-Kur'ân, thk. Yusuf Osman Fadlüllah Cibrîl (Riyad: Mektebetü'r-Rüşd, 1409/1989), 109-136; Ebû Abdirrahmân Ahmed b. Şuayb b. Ali el-Horasânî en-Nesâî, Fedâilü'l-Kur'ân, thk. Fârûk Hammâde (Beyrut: Dâru's-Sekâfe, 1413/1992), 102, 107. Ayrıca bk. Abdullah Aydemir, "Fezâilü'l-Kur'ân", Türkiye Diyanet Vakfı İslâm Ansiklopedisi (İstanbul: TDV Yayınları, 1995), 12/532-534. 
kullanılmaktadır. Ancak bunlardan bir kısmı sahih yahut "Fezâilü'l-a'mâl/Amellerin Faziletleri" konusunda itibar edilecek düzeyde zayıf olmakla beraber diğer bir kısmı uydurma yahut itibar edilemeyecek seviyede aşırı zayıf rivayetlerden oluşmaktadır.

Bu tür rivayetleri tespit etmek, kanaatimizce her zaman büyük bir önemi haiz meselelerdendir. Bu amaçtan hareketle araştırmada hâfızların faziletleri hakkında ve Kur'an'ın unutulmasının vebaline dair hadis olarak sunulan bazı sözlerin sıhhat durumu iki başlık altında incelenecektir.

\section{Kur'an'da Şefaat ve Hâfızların Şefaati Meselesi}

Şefaat kelimesi شَفَعَ يَشْفَع fiilinin masdarı olup kısaca aracılık etmek, başkası için istekte bulunmak anlamlarına gelir. ${ }^{7}$ Kur'an'da bu sözcük on bir defa geçmektedir. Bunlardan beş yerde elif lamsız ve izafesiz nekire isim olarak, beş yerde elif lam takısıyla marife isim olarak, birinde de muzâf isim olarak kullanılmıştır. Ayrıca on üç yerde isim türdeşleri zikredilmektedir. Bunlardan iki yerde ism-i fâil, beş yerde sıfat-ı müşebbehe, beş yerde sıfat-ı müşebbehenin çoğulu olarak شفعاء şeklinde, bir yerde de tek'in zıttı olan çift anlamında الشفع şeklinde câmid isim olarak kullanılmıştır. Yedi yerde ise muzari formatında fiil türevleri yer almaktadır. ${ }^{8}$

Şefaati konu edinen âyetlerden ${ }^{9}$ genel olarak âhiretteki şefaatla ilgili şu sonuçları çıkarmak mümkündür: 1. Şefaat ancak Allah'ın (c.c.) izin vermesi ve rızasıyla gerçekleşecektir. 2. Bazı insanlar (müşrikler, kâfirler ve münâfıklar) için herhangi bir şefaatçinin şefaat etmesi söz konusu değildir. 3. Sadece Allah'ın (c.c.) razı olduğu kişiler için şefaatçiler şefaat edebilecektir. 4. Yalnızca Allah'ın (c.c.) şefaat etmesine izin verdiği ve konuşmasına razı olduğu kişiler şefaat edebilecektir. Bunların kim olacağı hakkında ise Kur'an'da sadece melekler açıkça zikredilmiş, Hz. Peygamber'in (s.a.v.) şefaat edeceği teraccî sîgasıyla ifade edilmiş, ${ }^{10}$ diğer şefaatçilere ise genel olarak işaret edilmiştir.

7 Ebü'I-Kâsım el-Hüseyn b. Muhammed er-Râgıb el-İsfahânî, el-Müfredât fî garîbi'l-Kur'an, thk. Safvân Adnân edDâvîdî (Dımaşk: Dâru'I-Kalem, 1412), 458; Ebü'l-Fadl Cemâlüddîn Muhammed b. Mükerrem b. Ali İbn Manzûr er-Ruveyfi'î el-Ifrîkî, Lisânü'l-Arab (Beyrut: Dâru Sâdir, 1414), 8/184; Ebü'l-Feyz Muhammed b. Muhammed b. Abdirrezzâk el-Hüseynî Mürtezâ ez-Zebîdî, Tâcü'l-arûs min cevâhiri'l-kâmûs (Beyrut: Dâru'l-Hidâye, ts.), 21/282.

8 bk. el-Bakara 2/48; el-Bakara 2/123; el-Bakara 2/254; el-Bakara 2/255; en-Nisâ 4/85; el-Enâm 6/51; el-En'âm 6/70; el-En'âm 6/94; el-A'râf 7/53; Yunus 10/3; Yunus 10/18; Meryem 19/87; Tâhâ 20/109; el-Enbiyâ 21/28; eş-Şuarâ 26/100; er-Rûm 30/13; es-Secde 32/4; es-Sebe' 34/23; Yâsîn 36/23; ez-Zümer 39/43; ez-Zümer 39/44; el-Gâfir 40/18; ez-Zuhruf 43/86; en-Necm 53/26; el-Müddessir 74/48; el-Fecr, 89/3.

9 Kur'an'da şefaat başta olmak üzere şefaatla ilgili birtakım güncel çalışmalar da bulunmaktadır. Örnek olarak bazıları şunlardır: Hüseyin çelik, "Kur'an'da Şefaat", Tokat IImiyat Dergisi, 3/ 1, (Ocak 2015) 283-313; Mehmet Yılmaz, Kur'an'da Şefaat Kavramı ve Yaygın Şefaat Anlayışıyla Karşılaştırılması (İstanbul: Marmara Üniversitesi, Sosyal Bilimler Enstütüsü, Yüksek Lisans Tezi, İstanbul, 2006), 11-101.

10 bk. Ebû Ca'fer Muhammed b. Cerîr b. Yezîd et-Taberî, Câmi'u'l-beyân fî te'vîli'l-Kur'ân, thk. Ahmed Muhammed Şâkir (Beyrut: Müessesetü'r-Risâle, 1420/2000), 17/527; Ebû Muhammed Abdülhak b. Şâlib b. Abdirrahmân İbn Atıyye el-Endelüsî el-Muhâribî, el-Muharraru'I-vecîz fî tefsîri'l-Kitâbi'I-azîz, thk. Abdusselâm Abduşşâfî Muhammed (Beyrut: Dâru'l-Kütübi'I-IIImiyye, 1422), 3/478. 
Onların dışında şefaatçi olacakların kimler olabileceğine ise Kur'an'da değil birtakım hadislerde yer verilmiştir. Bu çalışmamızda hâfızların mezkûr gruplara dâhil olup olmadıkları, ardından da şefaat edebilecekleri insan sayısıyla ilgili muteber rivayetlerin olup olmadığı ortaya konulmaya çalışılacaktır.

\subsection{Bazı Kesimlerin Şefaati Konusu}

Hz. Peygamber'den (s.a.v.) nakledilen bazı hadislerden Kur'an hâfızlarından önce bizzat Kur'an'ın ${ }^{11}$ kendisinin şefaatçi olacağı anlaşılmaktadır. Nitekim Ebû Ümâme el-Bâhilî́den rivayet edilen bir hadiste Hz. Peygamber (s.a.v.) şöyle buyurmaktadır: "Kur'an'ı okuyun. Zira o kuşkusuz kıyamet günü ashâbına şefaatçi olarak gelecektir."122

Abdurrezzâk'ın bir senedle Abdullah b. Mes'ûd'un sözü olarak mevkûf; münkatı' olan diğer bir senedle ise merfû olarak kaydettiği bir rivayette de şöyle denilmektedir: "Şüphesi Kur'an hem şefaati kabul edilecek olan bir şefaatçi hem de tasdik edilecek olan mücadeleci bir hasımdır..."13

Kur'an'ın nasıl şefaat edeceğinin mahiyeti tam olarak bilinmemekle beraber bu konuda âlimler birtakım yorumlar yapmışlardır. Örneğin Münâvî (ö. 1031/1622) gibi bazı şârihlerin te'viline göre Allah (c.c.), mîzânda tartılabilmesi için kulların amellerine bir sûret ve ağırlık verecektir. Kur'an da insanların görebileceği bir sûretle temessül ederek şefaatçi olarak mahşere gelecektir. Zira Allah (c.c.) her şeye kâdirdir. ${ }^{14}$ Bazılarına göre de Kur'an'ın kendisi değil onu okumanın sevabı âhirette nefsiyle kâim bir şekilde gelip şefaatçi olacaktır. ${ }^{15}$

Bazı şârihlere göre ise şefaat fiilinin Kur'an'a isnâdı, bir şeyi sebebine isnâd etme kâbîlinden bir tür mecazdır. Asıl şefaat edecek olan melekler yahut Allah'ın (c.c.) şefaat etmesini dilediği başka kimselerdir. Kur'an sadece onların şefaatçi olmasına sebep olacaktır. ${ }^{16}$ Kimilerine göre de şefaatçiler, kişiler ve ameller olarak iki kısımdır. Kur'an'ın şefaati amellerin şefaatine dahildir. Buna göre Kur'an'ın

11 Kur'an'ın dışında Allah'ın (c.c.) indirdiği diğer kitaplar olan Tevrat, İncil ve Zebûr'un yahut suhufların şefaat edip etmeyeceğiyle ilgili herhangi bir rivayete rastlanmamıştır.

12 Ebü'l-Hüseyin Müslim b. el-Haccâc, Sahîhu Müslim, (İstanbul: Çağrı Yayınları, 1413/1992), Salâtü'l-Müsâfirîn ve Kasruhâ", 252; Ebü'l-Kâsım Süleyman b. Ahmed b. Eyyüb el-Lahmî et-Taberânî, el-Mu'cemu'l-evsat, thk. Târık b. Ivazıllah b. Muhammed -Abdulmuhsin b. İbrahim el-Hüseynî, (Kahire: Dâru'l-Haremeyn, ts.), 1/150; Ebû Abdillah Ahmed b. Muhammed b. Hanbel eş-Şeybânî, el-Müsned, (İstanbul: Çağrı Yayınları, 1413/1992), 5/249.

13 Her iki rivayet için bk. Ebû Bekir Abdurrezzâk b. Hemmâm b. Nâfi' el-Himyerî el-Yemânî es-San'ânî, el-Musannef, thk. Habîburrahmân el-Azamî (Beyrut: el-Mektebü'l-islâmî, 1403), 3/372.

14 bk. Zeynüddîn Muhammed Abdurraûf b. Tâcilârifîn b. Ali b. Zeynilâbidîn el-Haddâdî, el-Münâvî el-Kâhirî, etTeysîr bi şerhi'l-Câmi'i's-sağîr (Riyâd: Mektebetü'l-İmâm eş-Şâfi'î, 1408/1998), 1/193; Ebü'l-Hasan Ubeydullah b. Muhammed b. Abdisselâm er-Rahmânî el-Mübârekfûrî, Mir'âtü'l-mefâtîh şerhu Mişkâti'l-mesâbîh (Vârânasi: İâratü'l-Buhûsi'I-IIImiyyeti ve'd-Da'veti ve'I-Iftâ, 1404/1984), 7/188.

15 bk. Muhammed b. Sâlih b. Muhammed el-Useymîn, Şerhu Riyâzi's-sâlihîn (Riyad: Dâru'I-Vatan li'n-Neşr, 1426), 4/637.

16 bk. Muhammed el-Emîn b. Abdillah el-Üramî el-Alevî el-Herarî eş-Şâfi'î, el-Kevkebü'l-vehhâc ve'r-ravzu'l-behhâc fîş̧erhi Sahîhi Müslim b. el-Haccâc (Mekke: Dâru'I-Minhâc, 1430/2009), 10/152. 
kendisi değil okunması şefaat edecektir. ${ }^{17}$ Doğrusunu Allah (c.c.) bilir. Ancak sonuçta Kur'an'ın bir şekilde şefaatçi olacağı yahut şefaate sebep olacağı bahsi geçen rivayetlerden anlaşılmaktadır.

Allah'ın (c.c.) kelamı olan Kur'an'ın dışında mahşer günü insanlar içerisinden ilk ve en büyük şefaatçinin Hz. Peygamber (s.a.v.) olacağına dair birçok rivayet bulunmaktadır. Bunların en meşhurlarından biri, Kur'an'da "Makâm-ı mahmûd" diye ifade edilen ${ }^{18}$ ve âlimler tarafından "Şefâ'at-i uzmâ" olarak kavramsallaştırılan ${ }^{19} \mathrm{~Hz}$. Peygamber'in (s.a.v.) en kapsamlı şefaatiyle ilgili Buhârî ve Müslim başta olmak üzere birçok muhaddisin kaydettiği rivayettir. ${ }^{20}$

Araştırmalar sonucunda görüldüğü kadarıyla şefaatla ilgili rivayetler daha çok Hz. Peygamber'in (s.a.v.) şefaatiyle ilgilidir. Nitekim şefaatin ispatıyla alakalı yazılan müstakil eserlerde daha çok bu rivayetler yer almaktadır. ${ }^{21}$ Hatta Zehebî (ö. 748/1348) gibi bazı âlimler ilgili rivayetlerin çokluğundan yola çıkarak Hz. Peygamber'in (s.a.v.) şefaatini yedi kısma ayırmışlardır. ${ }^{22}$

Bazı rivayetlerden ise Hz. Peygamber'le (s.a.v.) birlikte diğer peygamberlerin, meleklerin ve şehitlerin de şefaat edecekleri anlaşılmaktadır. Nitekim Ebû Bekre'den rivayet edilen konuyla ilgili hadislerden birinde $\mathrm{Hz}$. Peygamber (s.a.v.) şöyle buyurmuştur: "Insanlar sırâtın üzerine taşınırlar ve her iki yanından kelebeklerin art arda ateşe düştükleri gibi cehennem ateşine düşmeye başlarlar. Önce Allah (c.c.), rahmetiyle dilediğini kurtarır. Sonra da meleklere, peygamberlere ve şehitlere şefaat etmeleri için izin verilir. Onlar da şefaat ederler..."23

17 bk. Ebû Zerr Abdülkâdir b. Mustafa b. Abdirrezzâk el-Muhammedî, eş-Şefâ'atü fi'l-hadisi'n-nebevî (Beyrut: Daru'lKütübi'l-IImiyye, 1426/2005), 138.

18 el-ìsrâ 17/79.

19 bk. Ebû Abdillah Şemsüddîn Muhammed b. Ahmed b. Osman b. Kaymaz ez-Zehebî, İsbâtü'ş-şefâ'a, thk. İbrâhim Bâcis Abdülmecîd (Nşr: Advâü's-Selef, 1420/200), 21.

20 Uzunca bir rivayet olduğu için çalışmada hadisin metnine yer verilmemiştir. Tam metin için bk. Buhârî, "Tefsîru'lKur'ân”, 5; Müslim, “Îmân”, 322; Tirmizî, “Kıyamet", 10.

21 Örnek olarak bk. Zehebî, İsbâtü'ş-şefâ'a, 20-66; Ebû Abdirrahmân Mukbil b. Hâdî b. Mukbil b. Kâide el-Hemedânî el-Vâdi'î, eş-Şefâ'a (San'a: Dâru'l-Âsâr li'n-Neşr ve't-Tevzî', 1420/1999), 25-195; Ebû Zerr el-Muhammedî, eşŞefâ'atü fi'l-hadisi'n-nebevî, 61-104.

22 Zehebî, ìsbâtü'ş-şefâ'a, 23.

23 Ebû Bekir Abdullah b. Muhammed b. İbrahim İbn Ebî Şeybe el-Absî, el-Musannef, thk. Kemal Yusuf el-Hût (Riyad: Mektebetü'r-Rüşd, 1409), 7/59; Ahmed b. Hanbel, el-Müsned, 20440; Ebû Bekir Ahmed b. Amr b. Abdilhâlık b. Hallâd b. Ubeydillah el-Bezzâr el-Atekî, el-Müsned: el-Bahru'z-zehhâr, thk. Mahfûzurrahmân Zeynullah (Medine: Mektebetü'l-Ulûm ve'l-Hikem, 1988-2009), 9/122. Heysemî (ö. 807/1405) hadisi rivayet eden ricâlin sahîhin ricali olduğunu söylemiştir. (bk. Ebü'l-Hasan Nûruddîn Ali b. Ebî Bekir b. Süleymân el-Heysemî, Mecme'u'z-zevâid ve menbe'u'l-fevâid, thk. Husâmüddîn el-Kudüsî (Kahire: Mektebetü'l-Kudüsî, 1414/1994), 10/359.) Ebü'l-Abbâs el-Bûsırî de hadisin râvilerinin sika olduğunu ifade etmiştir. (bk. Ebü'l-Abbâs Şihâbüddîn Ahmed b. Ebî Bekir b. İsmail b. Selîm b. Kaymaz b. Osman el-Bûsırî el-Kinânî, İthâfü'I-hîrati'l-mehera bi zevâidi'l-mesânîdi'l-aşere, thk. Ebû Temîm Yâsir b. İbrâhim (Riyad: Dâru'I-Vatan, 1420/1999), 8/166. 
Zikredilen şefaatçilerin dışında âlimlerin de şefaat edecek gruplardan biri olduğuna dair İbn Mâce'nin (ö. 273/887) ${ }^{24}$ Saîd b. Mervân > Ahmed b. Yunus $>$ Anbese b. Abdurrahmân > Allâk b. Ebû Süleym > Ebân b. Osman > Osman b. Affân kanalıyla rivayet ettiği ve özellikle günümüz vâizlerinin de çokça dile getirdiği ${ }^{25}$ şöyle bir rivayet bulunmaktadır: "Kıyamet günü şu üç kesim şefaat edecektir: Peygamberler, sonra âlimler, sonra da şehitler. ${ }^{26}$

Ancak zikredilen seneddeki Anbese b. Abdurrahman ve Allâk b. Ebû Süleym ta'dîl açısından problemli râvilerdendirler. Nitekim Bûsırî (ö. 840/1436), Allâk b. Ebû Süleym zayıf olduğu için mezkûr rivayetin isnâdının da zayıf olduğunu dile getirmiştir. ${ }^{27}$ Münâvî mezkûr rivayetle ilgili çelişkili bir şekilde bir yerde isnâdının hasen olduğunu ${ }^{28}$ diğer bir yerde ise Süyûtî́nin (ö. 911/1505) hasen olduğunu söylemesine itiraz ederek senedinde metrûk bir râvi olan ${ }^{29}$ Anbese b. Abdurrahman'ın bulunmasından hareketle zayıf olduğunu ifade etmiştir. ${ }^{30}$ Irâkî de (ö. 806/1404) zayıf olduğu görüşündedir. ${ }^{31}$ Elbânî ise önce Ebû Hâtim'in (ö. 277/890), Anbese hakkında "Hadis uydururdu." sözünü nakledip rivayetin mevzû olduğunu söylemiş, ardından Irâkî'yi tesâhül ile, Süyûtî́yi ondan daha kötü olmakla, Münâvî'yi de çelişkili ve mütesâhil tutumuyla eleştirmiştir. ${ }^{32}$

Zehebîmezkûr râviyle ilgili Buharî́nin (ö. 256/870), "Onu terk ettiler."; Ebû Zür’a (ö. 281/890) ve Nesâî́nin (ö. 303/915) "Zayıf"; ỉbn Hibbân'ın (ö. 354/965) "Onunla inticâc edilmez."; Yahyâ b. Ma'în'in de (ö. 233/848) "Hiçbir şey değil." dediğini nakletmiş, kendisi de onunla ilgili "Onda teşeyyu' vardır." değerlendirmesini yapmıştır. ${ }^{33}$ İbn Hibbân da Allâk b. Ebû Süleym hakkında şunları söylemiş̧tir: "Enes ve Ebân b. Osman'dan Sebt olanların hadisine benzemeyen şeyler rivayet eden

24 Ayrıca Beykakî, Âcurrî ve Kurtubî gibi bașka âlimler de bu rivayeti nakletmiștir. Ancak onların senedlerinde de cerh edilen mezkûr iki râvi bulunmaktadır. bk. Ebû Bekir Muhammed b. el-Hüseyin b. Abdillah el-Âcurrî, el-Bağdâdî, eş-Şerî'a, thk. Abdullah b. Ömer b. Süleyman ed-Dümeycî (Riyad: Dâru'I-Vatan, 1420/1999), 3/1246; Ebû Ömer Yusuf b. Abdillah b. Muhammed b. Abdilberr b. Âsım en-Nemerî el-Kurtubî, Câmi'u beyâni'l-ilm ve fazlih, thk. Ebü'l-Eşbâl ez-Züheyrî (Riyad: Dâru İbni'I-Cevzî, 1414/1994), 1/159.

25 Örnek olarak bk. https://www.youtube.com/watch?v=zdaMul-ckiQ, Erişim Tarihi: 06. 04. 2020.

26 Ebû Abdillah Muhammed b. Yezîd İbn Mâce, Sünenü İbn Mâce (İstanbul: Çağrı Yayınları, 1413/1992), "Zühd", 37.

27 bk. Ebü'l-Abbâs Şihâbüddîn Ahmed b. Ebî Bekir b. İsmail b. Selîm b. Kaymaz b. Osman el-Bûsırî el-Kinânî, Misbâhu'z-zücâce fî zevâidi İbn Mâce, thk. Muhammed el-Müntekâ el-Küşnâvî (Beyrut: Dâru'l-Arabiyye, 1403), 4/260.

28 Münâvî, et-Teysîr bi şerhi'l-Câmi'i's-sağîr, 2/508.

29 Anbese'nin metrûk ve hadisi münker bir râvi olduğuna dair bk. Ebû Ahmed İbn Adiyy el-Cürcânî, el-Kâmil fí du'afâi'r-ricâl, thk. Âdil Ahmed Abdülmevcûd - Ali Muhammed Muavvaz (Beyrut: Dâru'l-Kütübi'I-IIlmiyye, 1418/1997), 6/461.

30 Zeynüddîn Muhammed Abdurraûf b. Tâcilârifîn b. Ali b. Zeynilâbidîn el-Haddâdî, el-Münâvî el-Kâhirî, Feyzü'lkadîr şerhu'l-Câmi'i's-sağîr (Mısır: el-Mektebetü't-Ticâriyyeti'l-Kübrâ, 1356), 6/462.

31 Ebü'l-Fadl Zeynüddîn Abdurrahîm b. el-Hüseyin b. Abdirrahmân el-Irâkî, Tahrîcü ehâdîsi Ihyâii ulûmiddîn (Riyad: Dâru'l-Âsıme li'n-Neşr, 1408/1987), 1/38.

32 Ebû Abdirrahmân Muhammed Nâsıruddîn b. el-Hâc Nuh b. Necâtî b. Âdem el-Elbânî, Silsiletü'l-ehâdisi'd-daîfe ve'l-mevzû'a (Riyad: Dâru'I-Ma'ârif, 1412/1992), 4/445.

33 Ebû Abdillah Şemsüddîn Muhammed b. Ahmed b. Osman b. Kaymaz ez-Zehebî, Târihu'l-Islâm ve vefeyâtü'lmeşâhîri ve'l-'alâm, thk. Ömer Abdüsselâm et-Tedmürî (Beyrut: Dâru'l-Kitâbi'l-Arabî, 1413/1993), 11/286. 
bir şeyhtir. Rivayeti az olmakla beraber teferrüd ettiğinde onunla ihticâc caiz değildir."34

Bezzâr da (ö. 292/905) aynı senedle mezkûr hadisi rivayet etmiş ve Anbese'yle ilgili "Hadisi leyyindir." değerlendirmesini yapmıştır. Ayrıca onun naklettiği metin şu şekildedir: "Kıyamet günü ilk şefaat edecek olan peygamberlerdir. Sonra şehitler, sonra da müezzinler şefaat ederler." ${ }^{135}$ Görüldüğü gibi bu formatta âlimlerin yerine müezzinler üçüncü derecede zikredilmiştir.

Sonuç olarak mezkûr rivayetin ya uydurma ya da en azından itibar edilemeyecek düzeyde aşırı zayıf olduğu ortaya çıkmaktadır. Dolayısıyla peygamberler, melekler ve şehitlerin dışında spesifik olarak âlimlerin de şefaat edecek gruplardan biri olduğuna dair araştırmalar sonucunda muteber bir rivayete rastlanılmamıştır. Araştırmanın asıl konusu olan Kur'an hâfızlarının şefaat edecek grublardan biri olup olmadığı ve kaç kişiye şefaat etme haklarının olduğuna dair rivayetler ise aşağıda ele alınıp incelenecektir.

\subsection{Hâfızların Şefaat Hakkı}

İcazet merasimleri başta olmak üzere çeşitli platformlarda bazı kesimlerce Kur'an hâfızlarının ${ }^{36}$ mahşer günü şefaat edecek gruplardan biri olduğu ve yakınlarından yetmiş kişiye şefaat edecekleri ifade edilmektedir. ${ }^{37}$ Ancak araştırmalarımız sonucunda kaynaklarda mezkûr bilgiye dayanak olabilecek herhangi bir rivayete rastlanılmamıştır. Sadece belli şartları taşıyan Kur'an hâfızlarının yakınlarından on kişiye şefaat edeceklerine dair bir rivayet tespit edilmiştir. Binâenaleyh aşağıda bu rivayetin sıhhat durumu ele alınıp incelenecektir.

Ayrıca bazı rivayetlere göre yetmiş kişiye şefaat etme hakkı Kur'an hâfızları için değil şehitler için söz konusudur. Nitekim Ebü'd-Derdâ'dan rivayet edilen bir hadiste Hz. Peygamber (s.a.v.) şöyle buyurmuştur: "Şehit, ev halkından yetmiş kişi hakkında şefaatçi kılınır."138 Birtakım vasıfları haiz olan hâfızların ev halkından on kişiye şefaat edeceklerine dair rivayet ise üç sahâbî kanalıyla rivayet dilmiştir.

34 Ebû Hâtim Muhammed b. Hibbân b. Ahmed b. Hibbân b. Muâz b. Ma'bed et-Temîmî el-Büstî ed-dârimî, elMecrûhîn mine'l-muhaddisîn ve'd-duafâi ve'l-metrûkîn, thk. Mahmûd İbrâhim Zâyid (Halep: Dâru'I-Va'y, 1396), 2/174.

35 Bezzâr, el-Müsned: el-Bahru'z-zehhâr, 2/27.

36 Hâfız kavramıyla ilgili detaylı bilgi için bk. Nebi Bozkurt, "Hâfız", Türkiye Diyanet Vakfı İsâm Ansiklopedisi (İstanbul:TDV Yayınları, 1997), 15/74-78.

37 Örnek olarak bk. https://www.youtube.com/watch?v=TsPSLYWgp5w, Erişim Tarihi: 01.02.2020; https://forum. memurlar.net/konu/690542/, Erişim Tarihi: 08. 02. 2020.

38 Ebû Dâvûd Süleyman b. Eş'as, Sünenü Ebî Dâvûd, (İstanbul: Çağrı Yayınları, 1413/1992), "Cihâd", 26; Bezzâr, el-Müsned, 10/25; Ebû Hâtim Muhammed b. Hibbân b. Ahmed İbn Hibbân ed-Dârimî el-Büstî, Sahîh, thk. Şuayb el-Arnavut (Beyrut: Müessesetü'r-Risâle, 1414/1993), 10/517; Ebû Bekir Ahmed b. Hüseyin b. Ali b. Musa el-Horasânî el-Beyhakî, es-Sünenü'l-kübrâ, thk. Muhammed Abdulkâdir Atâ (Beyrut: Dâru'l-Kütübi'l-İlmiyye, 1424/2003), 9/277. Elbânî rivayetin sahîh olduğunu dile getirmiştir. bk. Ebû Abdirrahmân Muhammed Nâsıruddîn el-Elbânî, Sahîhu Ebî Dâvûd (Beyrut: Müessesetü Gırâs li'n-Neşr ve't-Tevzî', 1423/2002), 7/281. 
Bunlar Ali b. Ebû Tâlib, Câbir b. Abdullah ve Âişe'dir. Aşağıda bu rivayetler metin ve sened açısından incelenip değerlendirilecektir.

\subsection{1. İlgili Rivayetin Metin Değerlendirmesi}

Ali b. Ebû Tâlib rivayetini aradaki bazı lafız farklılıklarıyla beraber Ahmed b. Hanbel (ö. 241/855), Tirmizî (ö. 279/892), İbn Mâce, Âcurrî (ö. 360/970), Taberânî (ö. 360/971 ), İbn Şâhîn (öl. 385/996), Beyhakî (ö. 458/1066) ve İbn Asâkir (ö. 600/1203) olmak üzere toplam sekiz kişi nakletmektedir. Öncelikle Tirmizî́nin lafzı dikkate alınacak olursa rivayetin metni şu şekildedir:

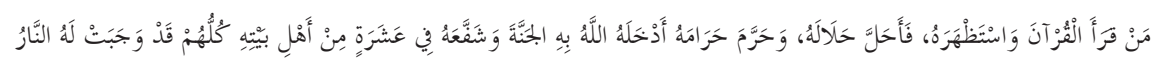

“Her kim Kur'an'ı okur, ezberler, helalini helal; haramını da haram sayarsa Allah (c.c.) onu Kur'an sebebiyle cennete koyar. Ev halkından da tamamına ateşin vacip olduğu on kişi hakkında onu ${ }^{39}$ şefaatçi kılar." 40

Diğerlerinin lafızlarına bakıldığında Ahmed b. Hanbel'in kaydettiği metinde

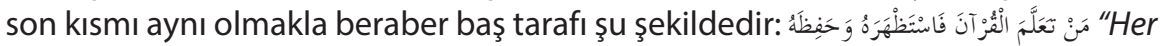
kim Kur'an'ı öğrenir, ezberler ve korursa..." ${ }^{41}$ Anlaşıldığı üzere bu metinde حفظ fiili bazı şârihlerin de belirttiği üzere ${ }^{42}$ "ezberlemek" anlamında değil helalini helal; haramını da haram sayıp içeriğiyle amel ederek "korumak" ya da ezberledikten sonra unutmamakla onu korumak anlamındadır. Zira "ezberlemek" anlamında fiili zaten daha önce zikredilmiştir.

Beyhakî'nin lafzı, Tirmizî́nin lafzıyla hemen hemen aynıdır. Sadece şart

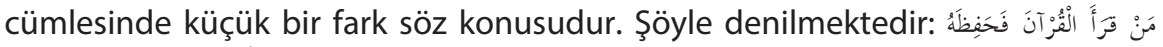

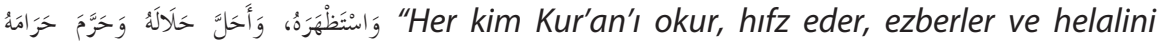
helal; haramını da haram sayarsa.." ${ }^{43}$ Buradaki حفili muhtemelen استظهر ile eş anlamlıdır. Anlamı pekiştirmek için gelmiştir. Zira diğer anlamıyla korumak zaten şeklinde hadiste ifade edilmektedir. Ayrıca İbn Asâkir'in lafzı büyük oranda Beykakî'ninki gibidir. Sadece şart cümlesinde önce استظهر fiili, sonra حف fiili zikredilmiş, ceza cümlesinde de sülâsî olan وجبتfiilinin yerine mezîd olan fiili zikredilmiştir. ${ }^{44}$

İbn Mâce'nin lafzında ceza cümlesi yine aynı olmakla beraber şart cümlesi

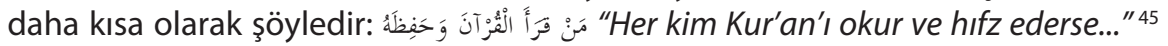

39 Buradaki zamiri kişiye değil de Kur'an'a ircâ ettirmek her ne kadar mümkün ise de ilk akla gelen cümlenin asıl öznesi ve menâtı olan kişiye râci olduğudur.

40 Ebû İsa Muhammed b. İsa b. Sevra et-Tirmizî, Sünenü't-Tirmizî, (İstanbul: Çağrı Yayınları, 1413/1992), “Fedâilü'lKur'an", 13.

41 Ahmed b. Hanbel, el-Müsned, 2/420.

42 Mübârekfûrî, Mirâtü'l-mefâtîh, 7/218.

43 Ebû Bekir Ahmed b. el-Hüseyin b. Ali b. Musa el-Horasânî, Şu'abu'l-îmân, thk. Abdülalî Abdülhamîd Hâmid (Riyad: Mektebetü'r-Rüşd, 1423/2003), 3/341.

44 Ebü'l-Kâsım Ali b. Hasan b. Hibetillah İbn Asâkir, Târîhu Dımaşk, thk. Amr b. Garâme el-Amrî (Beyrut: Dâru'l-Fikr, 1415/1995), 11/93.

45 İbn Mâce, "Mukaddime", 16. 
Buradaki حفظ fiili ezberlemek anlamında olabileceği gibi helalini helal; haramını da haram sayıp içeriğiyle amel ederek "korumak" anlamında da olabilir. İkinci ihtimale göre Kur'an'ı ezberleyenler değil onu hayata tatbik ederek koruyanlar kastedilmiştir.

Taberânî'nin kaydettiği lafzın şart cümlesi özellikle Ahmed b. Hanbel'inki gibi olup ${ }^{46}$ diğerleriyle benzeşse de asıl farklılık ceza cümlesinde bulunmaktadır.

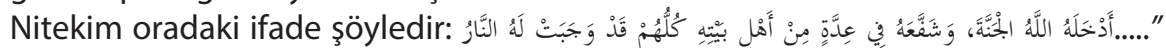
Allah (c.c.) onu cennete girdirir ve ev halkından kendileri için ateş vacip olan bir gruba onu şefaatçi kılar." 47 Görüldüğü gibi bu formatta hâfızların şefaat edeceği kişiler belli bir sayıyla sınırlandırılmamıştır. Zira عشرة kelimesi yerine عدة denilmiştir. Bu da belli bir sayıda kişi anlamındadır. Ancak sayı net değildir. Dolayısıyla buna göre her hâfızın şefaatçi kılınacağı kişi sayısı farklılık arz edebilir. On kişi, daha az kişi yahut daha fazla kişi olabilir. Âcurrî ve İbn Şâhîn'in lafızlarında ise şart cümlesi Taberânî́ninki gibi; ceza cümlesi de diğerlerininki gibidir. ${ }^{48}$

Câbir b. Abdullah rivayetine gelince tespit edilebildiği kadarıla sadece Taberânî bunu nakletmektedir. Hadisin metni şu şekildedir:

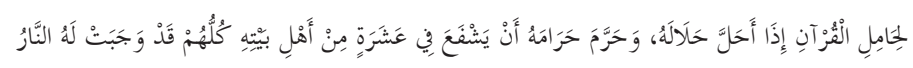

"Helalini helal; haramını da haram saydığı zaman Kur'an'ı yüklenen kişi için ev halkından kendilerine ateşin vacip olduğu on kişi hakkında şefaat etme hakkı vardır." ${ }^{\prime 49}$ Görüldüğü gibi bu metnin diğerlerinden lafızca farkı haber cümlesi olması ve Hâmilü'l-Kur'an ifadesini içermesidir. Mana açısından ise aynı şeyi anlatmaktadır.

Hz. Âişe rivayetini ise araştırmalara göre Hatîb el-Bağdâdî ve Sehâvî olmak üzere iki kişi nakletmiştir. Öncelikle Hatîb'in rivayeti İbn Mâce'nin lafzına benzer olup şu şekildedir:

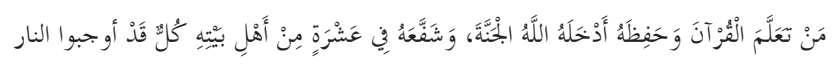

"Her kim Kur'an'ı öğrenir ve korursa/ezberlerse Allah (c.c.) onu cennete girdirir ve hepsi ateşi kendilerine vacip kılmış olan ev halkından on kişi hakkında onu şefaatçi kılar." ${ }^{\prime 50}$

Sehâvî'nin kaydettiği metin ise Tirmizî'ninkine benzer bir şekilde şöyledir:

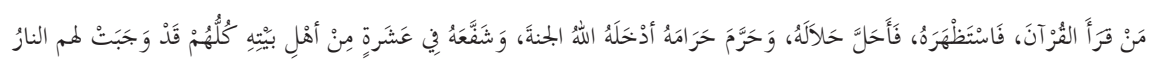

46 Sadece تعلم filinin yerinde fiili kullanılmıştır.

47 Taberânî, el-Mu'cemu'l-evsat, 5/217.

48 Âcurrî, eş-Şerî́a, 3/1246; Ebû Hafs Ömer b. Ahmed b. Osman b. Ahmed İbn Şâhîn el-Bağdâdî, et-Terğîb fî fezâili'l'amâl ve sevâbü zâlik, thk. Muhammed Hasan Muhammed Hasan İsmail (Beyrut: Dâru'l-Kütübi'l-Illmiyye, 1424/2004), 66.

49 Taberânî, el-Mu'cemu'l-evsat, 5/260.

50 Ebû Bekir Ahmed b. Ali b. Sâbit el-Hatîb el-Bağdâdî, Târîhu Bağdâd ve Züyûlüh (Beyrut: Dâru'l-Kütübi'l-IImiyye, 1417), 4/301; 5/195; $11 / 394$. 
"Her kim Kur'an'ı okur, ezberler, helalini helal; haramını da haram sayarsa ezberlerse Allah (c.c.) onu cennete girdirir ve hepsi ateşin vacip olduğu ev halkından on kişi hakkında onu şefaatçi kılar."151

Sonuç olarak rivayetlerin tümü ele alındığı zaman bahsi geçen on bir rivayete göre şu dört vasfı haiz olan kişinin ev halkından on kişiye yahut belli sayıda bir gruba mahşer günü şefaat edebileceği anlaşılmaktadır:

a. Kur'an'ı öğrenmesi

b. Kur'an'ı okuması/okumaya devam etmesi

c. Kur'an'ı unutmayıp koruması/yaşayarak hükümlerini muhafaza etmesi

d. Kur'an'ın helalini helal, haramını da haram sayması/Kur'an'ı yaşaması

Dolayısıyla bu vasıfların tamamına sahip olmadığı halde sadece Kur'an'ı ezberlediği için dünyada hâfızlık unvanına sahip olan kişinin, başkasına şefaat etmesi bir tarafa, okuyup ezberlediği Kur'an'ı yaşamadığı için Allah'a (c.c.) nasıl hesap vereceği ve kendini ateşten ne şekilde kurtarabileceği üzerinde ciddi olarak düşünüp muhasebe yapması gerekmektedir. Ayrıca çeşitli platformlarda konuyla ilgili farklı rivayetler kullanılıp insanlar hâfızlığa teşvik edilirken kanaatimizce bu konu; "Hâfızlar şu faziletlere sahiptir." gibi cümlelerle değil, "Şu vasıfları haiz olan hâfızlar şöyle faziletlere sahiptir." gibi söylemlerle işlenmelidir. Aksi halde mezkûr vasıflara sahip olsun ya da olmasın her hâfızın bu tür faziletlere nail olabileceği gibi yanlış bir algı toplumda oluşmaktadır.

\subsection{2. İlgili Rivayetlerin Sened Yönünden İncelenmesi}

Zikredilen rivayetlerden birinci grubu oluşturan Ali b. Ebû Tâlib rivayetlerinin senedlerinde yer alan râvilerden güvenilirliği konusunda problem olan iki râvi bulunmaktadır. ${ }^{52}$ Bunlardan ilki meşhur kıraat âlimi Âsım'ın (ö. 127/745) iki râvisinden biri olan Ebû Ömer Hafs b. Süleyman olup diğeri de şeyhi Kesîr b. Zâzân'dır. Sadece Taberânî'nin kaydettiği Câbir b. Abdullah rivayetinin senedindeki râvilerden de sika oluşlarında ihtilaf bulunan yine iki kişi vardır. Bunlar Selm b. Sâlim ile şeyhi Ca'fer b. el-Hâristir. ${ }^{53}$ Öncelikle sırasıyla bu râviler hakkında hadis münekkitlerinin değerlendirmeleri aktarılacaktır. Ardından bunlar arasında bir tercih ve kanaat ortaya konulmaya çalışılacaktır.

51 Ebü'l-Hasan Alemüddîn Ali b. Muhammed b. Abdissamed el-Hemedânî el-Mısrî eş-Şâfiî es-Sehâvî, Cemâlü'lKurrâ ve kemâlü'I-Ikrâ, thk. Mervân el-Atıyye - Muhsin Harâbe (Dımaşk: Dâru'I-Me'mûn li't-Türâs, 1418/1997), 181.

52 Diğer râvilerin kimliği ve sika olduğu hakkında detaylı bilgi için bk. Mesut Çakır, Fezâilü'l-Kur'an Hadisleri Çerçevesinde Kur'an'ın Ezberlenmesi ile Illgili Rivayetlerin Tahrîc ve Değerlendirilmesi, Marmara Üniversitesi Sosyal Bilimler Enstitüsü, 68-79.

53 Diğer râvilerin kimliği ve sika olduğu hakkında detaylı bilgi için bk. Çakır, Fezâilü'l-Kur'an Hadisleri Çerçevesinde Kur'an’ın Ezberlenmesi ile Ilgili Rivayetlerin Tahrîc ve Değerlendirilmesi, 79-82. 


\subsubsection{Ali b. Ebû Tâlib Rivayetinin Sened Tenkidi}

Zikredilen rivayetlerin birinci grubunu oluşturan Ali b. Ebû Tâlib rivayetlerinin senedlerinde problemli iki râvi bulunmaktadır. ${ }^{54}$ Bunlardan ilki Ebû Ömer Hafs b. Süleyman olup diğeri de şeyhi Kesîr b. Zâzân'dır.

Öncelikle Ebû Ömer Hafs b. Süleyman'a bakılacak olursa Zehebî'nin naklettiğine göre o Şeyhu'l-kurrâ Ebû Ömer Hafs b. Süleyman el-Esedî el-Gâdırî el-Küfî'dir. Ona Hafs b. Ebû Dâvûd da denilir. Kıraatta huccet olmakla beraber hadiste vâhîdir/zayıftır. Annesinin eşi Âsım b. Ebü'n-Necûd'dan kıraat eğitimini almıştır. Alkama b. Mersed, Sâbit el-Bünânî, İbn İshak, Kesîr b. Zâzân, Muhârib b. Disâr, İsmail es-Süddî, Leys b. Ebû Süleym ve bir gruptan rivayette bulunmuştur. Onunla ilgili Buhârî, "Onu terk ettiler."; ${ }^{55}$ Yahyâ b. Maîn, "Bir şey değil."; Sâlih Cezera (ö. 293/906), "Hadisi yazılmaz."; Zekeriyya es-Sâcî (ö. 307/920), "Kays b. Müslim ve bir gruptan batıl hadisler nakletmiştir."; İbn Adiyy (ö. 365/976), "Hadislerinin çoğunluğu mahfûz değildir."; Şu'be, "İnsanların kitaplarını ödünç alıp bir nüshasını çıkarırdı. Benden de bir kitap aldı. Ancak geri vermedi." demiştir. ${ }^{56}$ Ahmed b. Hanbel onun hakkında bir seferinde, "Onda bir beis yoktur."; diğer seferinde ise "Hadisi metrûktur." ifadesini kullanmıştır. Zehebî'ye göre onun hakkındaki bu olumsuz tenkitlerin sebebi hadiste gevşeklik göstermesidir. ${ }^{57}$ Ayrıca Yahya b. Mâin onunla ilgili, "Sika değildir."; ${ }^{8}$ Buhârî ise "Onun hakkında sükût ettiler." ${ }^{59}$ değerlendirmesinde bulunmuştur. Nesâî de onun için "Metrûkü'lhadis/hadisi terkedilen" tabirini kullanmıştır. ${ }^{60}$

Benzer şekilde İbn Ebû Hâtim'in (ö. 327/938) naklettiğine göre onun hakkında Ebû Zür'a, "Hadisi zayıftır." demiş, babası Ebû Hâtim de "Hadisi yazılmaz. Hadisi zayıftır. Doğru söylemez. Hadisi metrûktur." gibi tenkidler de bulunmuştur. Ona kıraattaki durumunu sorduğunda da "Ebû Bekir b. Ayyâş ondan daha sebttir/ sağlamdır." İfadesini kullanmıştır. ${ }^{61}$ İbn Adiyy ise Yahya b. Mâîn'in onun hakkında şöyle dediğini nakletmiştir: "Kıraat sahibi olan Ebû Ömer el-Bezzâz (hadiste) sika

54 Diğer râvilerin kimliği ve sika olduğu hakkında detaylı bilgi için bk. Çakır, Fezâilü'l-Kur'an Hadisleri Çerçevesinde Kur'an'ın Ezberlenmesi ile llgili Rivayetlerin Tahrîc ve Değerlendirilmesi, 68-79.

55 Ayrıca bk. Ebû Abdillah Muhammed b. İsmail b. İbrahim b. el-Muğîra el-Buhârî, et-Târîhu'l-kebîr (Haydarabâd: Dâiratü'l-Ma'ârifi'l-Osmâniyye, ts.), 2/363.

56 Ayrıca bk. Ebû Abdillah Muhammed b. İsmail b. İbrahim b. el-Muğîra el-Buhârî, ed-Duafâü's-sağîr, thk. Ebî Abdillah Ahmed b. İbrâhim b. Ebi'l-Ayneyn (b.y: Mektebetü Ibn Abbâs, 1426/2005), 45.

57 Ebû Abdillah Şemsüddîn Muhammed b. Ahmed b. Osmân b. Kaymâz ez-Zehebî, Târîhu'l-Islâm, thk. Ömer Abdusselâm et-Tedmürî (Beyrut: Dâru'l-Kitâbi'l-Arabî, 1413/1993), 11/86.

58 Ebû Zekeriyya Yahya b. Maîn b. Avn b. Ziyâd b. Bestâm b. Abdurrahmân el-Mürrî el-Bağdâdî, Târihu İbn Maîn, thk. Ahmed Muhammed Nûr Seyf (Dımaşk: Dâru'I-Me'mûn li't-Türâs, ts.), 97.

59 Ebû Abdillah Muhammed b. İsmail b. İbrahim b. el-Muğîra el-Buhârî, et-Târîhu'l-evsat, thk. Mahmûd İbrahim Zâyid (Halep: Dâru'I-Va'y, 1397/1977), 2/256.

60 İbn Adiyy, el-Kâmil fì du'afâi'r-ricâl, 3/269.

61 Ebû Muhammed Abdurrahman b. Muhammed b. İdris b. el-Münzir İbn Ebî Hâtim et-Temîmî el-Hanzalî er-Râzî, el-Cerh ve't-ta'dîl (Haydarabâd: Dâiratü'l-Ma'ârifi'l-Osmâniyye, 1371/1952), 3/173. 
değildir. Ancak Ebû Bekir b. Ayyâş'tan kıraat açısından daha sahihtir. Fakat Ebû Bekir ondan daha sikadır." 62

İbn Hibbân da bir eserinde onun sadece zayıf olduğunu dile getirmiş, ${ }^{63}$ başka bir eserinde ise bunun sebeblerini şöyle açıklamıştır: " İsnâdlarda değişiklik yapıyordu. Sahâbî râvisi bulunmayan rivayetlerin senedine sahâbî râvisi koyuyordu. İnsanların kitaplarını alıp nüshasını çıkarıyor ve onlardan işitmeksizin hadislerini rivayet ediyordu. ${ }^{164}$

Kesîr b. Zâzân'a gelince Yahya b. Maîn kendisine bu râvinin kim olduğu sorulduğunda "Onu tanımıyorum." diye cevap vermiştir. ${ }^{65}$ Ebû Hâtim ve Ebû Zür’a da onunla ilgili şunu söylemişlerdir: "Mechûl bir şeyhtir. İbn Humeyd'in, Harun b. Muğîra > Anbese > Kesîr b. Zâzân senediyle rivayeti hariç ondan hiç bir kimsenin rivayette bulunduğunu bilmiyoruz." ${ }^{66}$ İbn Adiyy ise, "Ondan Hafs b. Süleyman ve başkaları rivayette bulunmuştur." demekle beraber ${ }^{67}$ başka bir değerlendirme yapmamıştır. Sadece Yahya b. Maîn'in onu tanımadığını nakletmiştir. ${ }^{68}$

Zehebî onun hakkında, "Hadisi sâbit olmaz.", 69 "Onun kimliğinde cehâlet vardır." ${ }^{70}$ "Onun münker hadisi vardır." ${ }^{71}$ "Tâbiînden olup tanınmayan Küfeli bir kişidir."72 ifadelerini kullanmıştır. Son olarak İbn Hacer'in kaydettiğine göre Ezdî onunla ilgili, "Onda nazar vardır."; Hatîb de "O Süfyân'ın kendisinden rivayette bulunduğu Neha' kabilesinin müezzinidir." demiştir. ${ }^{73}$ Hadis münekkitlerinin mezkûr değerlendirmelerinden her iki râvinin de zayıf olduğu açıkça anlaşılmaktadır. Dolayısıyla rivayetin bu senediyle zayıf olduğu sonucu ortaya çıkmaktadır.

62 İbn Adiyy, el-Kâmil fì du'afâi'r-ricâl, 3/268.

63 Ebû Hâtim Muhammed b. Hibbân b. Ahmed b. Hibbân b. Muâz b. Ma'bed et-Temîmî ed-Dârimî el-Büstî, es-Sikât (Haydarabâd: Dâiratü'l-Ma'ârifi'l-Osmâniyye, 1393/1973),

64 Ebû Hâtim Muhammed b. Hibbân b. Ahmed b. Hibbân b. Muâz b. Ma'bed et-Temîmî ed-Dârimî el-Büstî, elMecrûhîn mine'l-muhaddisîn ve'd-duafâ v'l-metrûkîn, thk. Mahmud İbrahim Zâyid (Halep: Dâru'l-Va'y, 1397/1977), $1 / 255$.

65 Yahya b. Maîn, Târihu ibn Maîn, 97.

66 Ebû Muhammed Abdurrahmân b. Muhammed b. İdrîs b. el-Münzir et-Temîmî el-Hanzalî İbn Ebî Hâtim er-Râzî, el-Cerh ve't-Ta'dîl, (Haydarabâd: Dâiratü'l-Ma'ârifi'l-Osmâniyye, 1271/1952), 7/151.

67 İbn Adiyy, el-Kâmil fì du'afâi'r-ricâl, 3/269.

68 İbn Adiyy, el-Kâmil fì du'afâi'r-ricâl, 3/268.

69 Ebû Abdillah Şemsüddîn Muhammed b. Ahmed b. Osman b. Kaymaz ez-Zehebî, el-Kâșif fî ma'rifeti men lehü rivayetün fi'l-kütübi's-sitte, thk. Muhammed Avvâme - Ahmed Muhammed Nemir el-Hatîb (Cidde: Dâru'l-Kıble li's-Sekâfeti'l-islâmiyye, 1413/1992), 2/143.

70 Ebû Abdillah Şemsüddîn Muhammed b. Ahmed b. Osman b. Kaymaz ez-Zehebî, Siyeru 'alâmi'n-nübelâ, thk. Şuayb el-Arnaût (Beyrut: Müessesetü'r-Risâle, 1405/1985), 13/306.

71 Ebû Abdillah Şemsüddîn Muhammed b. Ahmed b. Osman b. Kaymaz ez-Zehebî, Mîzânü'l-i'tidâl fî nakdi'r-ricâl, thk. Ali Muhammed el-Becâvî 4 Cilt. (Beyrut: Dâru'l-Ma'rife, 1382/1963), 3/403.

72 Ebû Abdillah Şemsüddîn Muhammed b. Ahmed b. Osman b. Kaymaz ez-Zehebî, Dîvânü'd-duafâ ve'l-metrûkîn ve halkin mine'l-mechûlîn ve sikâtin fihim lîn, thk. Hammâd b. Muhammed el-Ensârî (Mekke: Mektebetü'nNahdati'l-Hadise, 1387/1967), 329.

73 Ebü'l-Fadl Ahmed b. Ali b. Muhammed b. Ahmed b. Hacer el-Askalânî, Tehzîbü’t-Tehzîb (Hindistan: Matba'atü Dâirati'l-Ma'ârifi'n-Nizâmiyye, 1326), 8/412. 


\subsubsection{Câbir b. Abdullah Rivayetinin Sened Tenkidi}

Sadece Taberânî́nin kaydettiği Câbir b. Abdullah rivayetinin senedindeki râvilerden de sika oluşlarında ihtilaf bulunan yine iki kişi vardır. Bunlar Selm b. Sâlim ile şeyhi Ca'fer b. el-Hâristir. ${ }^{74}$

Öncelikle Selm b. Sâlim ele alınacak olursa İbnü'l-Cevzî (ö. 597/1201), İbnü'lMübârek'in (ö. 181/797) onu tekzîb ettiğini; Yahya b. Maîn'in onunla ilgili, "Hadisi bir şey değildir." ${ }^{75}$ dediğini nakletmiştir. ${ }^{76}$ İbnü'l-Kattân da (ö. 628/1231) zayıf ${ }^{77}$, mürciî/ircâ fikrini benimseyen, müttehem/yalancılıkla itham edilen ve metrûkü'lhadis/hadisi terkedilen biri olduğunu söylemiştir. ${ }^{78}$ Ayrıca Ebû Zür'a'nın onunla ilgili kendisine "Hadiste nasıl idi?" diye sorulunca, "Hadisi yazılmaz. Mürciî idi ve (eliyle ağzına işaret ederek) doğru söylemezdi." diye cevap verdiğini; İbnü'lMübârek'in bir seferinde, "O Selm'in akreplerindendir.", ${ }^{79}$ diğer seferinde de, "Selm'in yılanlarına karşı dikkatli ol! Seni sokmasın!" diye tenkitte bulunduğunu nakletmiştir. ${ }^{80}$ Yine Nesâî bu kişinin zayıf olduğunu; ${ }^{81}$ Cevzecânî de (ö. 256/872) sika olmadığını dile getirmiştir. ${ }^{82}$

Bu tür tenkidlerin yanı sıra onunla ilgili İbn Adiyy "Onda bir beis olmadığını ve hadisinin tahammül edilebileceğini umarım." şeklinde olumlu bir değerlendirme yapmıştır. ${ }^{83}$ Selm b. Sâlim münekkidlerin çoğunluğuna göre hadiste zayıf olmakla beraber Hatîb el-Bağdâdî́nin naklettiğine göre zühd ve takva sahibi olmakla bilinen ve emr-i bi'l-ma'rûf nehy-i ani'l-münker konusunda hassas bir kişiliktir. Onun bu yönleri hakkında birçok kişi övgü dolu sözler sarf etmişlerdir. Ancak Ahmed b. Hanbel onunla ilgili şunu söylemiştir: "Selm salih bir kuldu. Ondan hiçbir şey yazmadım. Zira hadisi hıfz edemeyip hata yapardı." ${ }^{84}$ Zehebî de bu râvi hakkında benzer nakiller yapmıştır. ${ }^{85}$ Ayrıca İclî́nin (ö. 261/875) onun için "Onda bir beis yoktur." dediğini kaydetmiştir. ${ }^{86}$ Görüldüğü gibi münekkidlerin bazıları onu tevsik etmekle beraber çoğunluğu cerh etmiştir.

74 Diğer râvilerin kimliği ve sika olduğu hakkında detaylı bilgi için bk. Çakır, Fezâilü'l-Kur'an Hadisleri Çerçevesinde Kur'an'ın Ezberlenmesi ile Ilgili Rivayetlerin Tahrîc ve Değerlendirilmesi, 79-82.

75 Ayrıca bk. İbn Hibbân, el-Mecrûhîn, 1/344; İbn Adiyy, el-Kâmil fí duafâi'r-ricâl, 4/348.

76 Ebü'l-Ferec Cemâlüddîn Abdurrahmân b. Ali b. Muhammed el-Cevzî, et-Tahkîk fî ehâdîsi'l-hilâf, thk. Müs'id Abdülhamîd (Beyrut: Dâru'I-Kütübi'l-IImiyye, 1415), 2/300.

77 Ebü'l-Hasan Ali b. Muhammed b. Abdilmelik İbnü'l-Kattân el-Kettâmî el-Himyerî el-Fâsî, Beyânü'l-vehm ve'lîhâm fî Kitâbi'l-Ahkâm, thk. el-Hüseyin Âyet Saîd (Riyad: Dâru Taybe, 1418/1997), 2/228.

78 İbnü'l-Kattân, Beyânü'l-vehm ve'l-îhâm, 3/172.

79 Ayrıca bk. İbn Ebû Hâtim, el-Cerh ve't-ta'dîl, 1/273.

80 İbnül'-Kattân, Beyânül'-vehm ve'l-îhâm, 3/210.

81 Nesâî, ed-Duafâ ve'l-metrûkün, 1/46.

82 Ebû İshak İbrâhim b. Yakûb b. İshak es-Sa'dî el-Cevzecânî, Ahvâlürr-ricâl, thk. Abdülalîm Abdülazîm el-Bestevî (Faysalabâd: Hadis Akademi, ts.), 352.

83 İbn Adiyy, el-Kâmil fì duafâi'r-ricâl, 4/349.

84 Hatîb el-bağdâdî, Tarîhu Bağdad, 9/141.

85 Zehebî, Siyeru a'lâmi'n-nübelâ, 8/76; a.mlf., Mîzânü'l-i'tidâl, 2/185.

86 Zehebî, Mîzânü'l-i'tidâl, 3/63. 
İkinci olarak Ebü'l-Eşheb Ca' fer b. el-Hâris en-Nehaî'ye gelince bu râvi hakkında münekkidler iki gruba ayrılmışlardır. Bazıları onu tad'îf ederken diğerleri onu tevsik etmiştir. Tad'îf edenlerden Fesevî (ö. 277/890), "Onda zayıflık vardır.";"77 Yahya b. Maîn, "Sika değildir. Hadisi bir şey değildir. Hadisi zayıftır." 88 Buhârî bir sefer, "hadisi münkerdir." 89 diğer bir sefer, "hıfzında bir şey vardır. Hadisi yazılır."; ${ }^{90}$ Nesâî, "zayıftır."191 Zehebî, "Onu tad'îf ettiler." ${ }^{\prime 92}$ demiştir.

Tevsik edenlerden Yezîd b. Hârûn (ö. 206/821), "Sika ve sadûk idi.";;93 Ebû Hâtim, "Hadisinde beis bulunmayan bir şeyhtir."; Ebû Zür'a, "Bana göre onda bir beis yoktur.";94 Ahmed b. Hanbel, "Sikalardandır."95 Hâkim (ö. 405/1014), "Etbâu'ttâbiînden olup Müslümanların sika imamlarındandır."96 İbn Kutluboğa (ö. 879/1474), "Sika sikadır."; ${ }^{97}$ İbn Hibbân ise bir eserinde," "Sikatün sikatün." ${ }^{98}$ diğer eserinde de, "Ara ara hata yapardı. Hakikatte cerh edilenlerden biri olacak kadar hatası çok değildir. Fakat teferrüd ettiğinde kendisiyle inticâc edilmez. Sikaya yakındır." ${ }^{\prime \prime 9}$ demiştir.

Sonuç olarak rivayetin bu senedinin bir öncekinden daha sağlam olduğu anlaşılmakla beraber özellikle birinci râvinin durumundan ötürü hadisin tamamen zayıflıktan kurtulduğunu söylemek de mümkün değildir.

\subsubsection{Hz. Âişe Rivayetinin Sened Tenkidi}

Daha önce de ifade edildiği gibi tespit edilebildiği kadarıyla bu rivayeti Hatîb el-Bağdâdî (ö. 463/1071) ve Sehâvî (ö. 902/1497) nakletmektedir. Öncelikle Hatîb el-Bağdâdî, kaydettiği Âişe rivayetinin senedinde bulunan râvilerden biri hariç diğerlerinin sika olduğunu ve bu bir râvi dolayısıyla hadisin, isnâdı münker olup ${ }^{100}$ sahih yahut hasen olmadığını ${ }^{101}$ ifade etmiştir. ${ }^{102} \mathrm{Bu}$ şahısdan sonra sened yukarıya doğru şöyle devam etmektedir: Yahya b. Maîn b. Avn Ebû Zekeriyya > Ebû Bekir Abdurrezzâk > Ma'mer > Zührî > Urve > Âişe.

87 Ebû Yusuf Yakûb b. Süfyân b. Civân el-Fârisî el-Fesevî, el-Ma'rife ve't-târîh, thk. Ekrem Dıyâ el-Ömerî (Beyrut: Müessesetü'r-Risâle, 1401/1981), 3/238.

88 Yahya b. Maîn, Târihu ibn Maîn, 399,406,487.

89 Buhârî, ed-Duafâü's-sağîr, $1 / 24$.

90 Zehebî, Mîzânü'l-i'tidâl, 1/405.

91 Nesâî, "ed-Duafâ ve'l-metrûkûn, 1/28.

92 Zehebî, Dîvânü'd-duafâ, 63.

93 Buhârî, et-Târîhu'l-kebîr, 2/189

94 İbn Ebû Hâtim, el-Cerh ve't-ta'dîl, 2/476.

95 Ebû Hafs Ömer b. Ahmed b. Osman b. Ahmed b. Muhammed b. Eyyûb İbn Şâhîn el-Bağdâdî, el-Mühtelef fihim, thk. Abdurrahîm b. Muhammed b. Ahmed el-Kaşkarî (Riyad: Mektebetü'r-Rüşd, 1420/1999), 75.

96 Ebü'l-Fadl Ahmed b. Ali b. Muhammed b. Ahmed b. Hacer el-Askalânî, Tehzîbü't-Tehzîb (Hindistan: Dâiratü'lMa'ârifi'n-Nizâmiyye, 1326), 2/88.

97 Ebü'l-Fidâ Zeynüddîn Kasım b. Kutluboğa es-Sûdûnî el-Cemâlî el-Hanefî, es-Sikât mimmen lem yeka' fi'lkütübi'sw-sitte, thk. Şâdî b. Muhammed b. Sâlim Âl-i Numân (San'â: Mektebetü'n-Numân, 1432/2011), 3/172.

98 İbn Hibbân, es-Sikât, 6/139.

99 İbn Hibbân, el-Mecrûhîn, 1/212.

100 Hâtîb el-Bâğdâdî, Târîhu Bağdâd ve züyûlüh, 4/301.

101 Hâtîb el-Bâğdâdî, Târîhu Bağdâd ve züyûlüh, 5/196.

102 Hâtîb el-Bâğdâdî, Târîhu Bağdâd ve züyûlüh, 4/301. 
Rivayeti Yahya b. Mâin'den nakleden bu râvinin ismini ise bir yerde Ebû Hubeyş (Ebû Haneş) Ahmed b. el-Hasan olarak, ${ }^{103}$ bir yerde Ebü'l-Hüseyn Ahmed b. Muhammed b. el-Hüseyin es-Sakatî olarak, ${ }^{104}$ diğer bir yerde de Ebü'l-Hasan Ali b. el-Hüseyin es-Sakatî olarak ${ }^{105}$ kaydetmiştir. Böylece üç farklı şahsın Yahya b. Maîn'den bu rivayeti naklettiği anlaşılmaktadır. Dolayısıyla ilgili rivayetin sened tenkidi bu üç şahıs üzerinden yapılacaktır.

Birinci râviyle ilgili Zehebî sadece, Hatîb'in onu mezkûr rivayeti Yahya b. Maîn adına uydurmakla itham ettiğini söylemekle yetinmiştir. Başka bir değerlendirme yahut nakil yapmamıştır. ${ }^{106}$ İkinci râvinin de mevzû bir haber nakletmiş, tanınmayan belirsiz bir kişi olduğunu söylemiştir. ${ }^{107}$ Ayrıca her iki râvinin aynı şahıs olabileceğini dile getirmiştir. ${ }^{108}$

İbn Arrâk'ın (ö. 963/1556) kaydettiğine göre İbn Hacer (ö. 852/1449), Hatîb'in rivayetle ilgili olumsuz görüşünü aktardıktan sonra bu üç râvinin aynı kişiler mi yoksa farklı kişiler mi olduğu hususundaki tereddüdünü şu şekilde dile getirmiştir: "Bilmiyorum! Hadisin senedinde sakatî nisbesiyle anılanlar mezkûr hadisi aynı senedle rivayet etmek üzere birleşen farklı kişiler midir? Yoksa ismi ve nisbesinde karışıklık bulunan tek bir şahıs mıdır? Bu konuya değinen hiç kimseyi de görmedim." 109 İbnü'l-Cevzî ve Fettenî de (ö. 986/1578) bu rivayeti incelerken Hatîb'in sâbit olmadığına dair ifadesini aktarmakla yetinmiştir. ${ }^{110}$ Dolayısıyla rivayetin bu senediyle de zayıf olduğunu söylemek pekâlâ mümkündür.

Sehâvî́nin senedi ise öncelikle Ebü'l-Fadl Muhammed b. Yusuf elGaznevî'den başlayarak Tirmizî'ye uzanmaktadır. Ardından Âişe'ye ulaşmaktadır. Bütün olarak şu şekildedir: Ebü'l-Fadl Muhammed b. Yusuf elGaznevî > Abdülmelik b. Ebü'l-Kâsım el-Herevî > Ebû Âmir Mahmûd b. el-Kâsım el-Ezdî > Ebû Muhammed Abdülcebbâr b. Muhammed el-Cerrâhî > Ebü'lAbbâs Muhammed b. Ahmed el-Mahbûbî > Ebû İsa et-Tirmizî > Mahmûd b.

103 Hâtîb el-Bâğdâdî, Târîhu Bağdâd ve züyûlüh, 4/301.

104 Hâtîb el-Bâğdâdî, Târîhu Bağdâd ve züyûlüh, 5/196.

105 Hâtîb el-Bâğdâdî, Târîhu Bağdâd ve züyûlüh, 11/394.

106 Zehebî, Mîzânü'l-i'tidâl, 1/91.

107 Zehebî, Mîzânül'-i'tidâl, 1/145.

108 Zehebî, Mîzânü'l-i'tidâl, 1/431, 601.

109 Nûruddîn Ali b. Muhammed b. Ali b. Abdurrahman b. Arrâk el-Kinânî, Tenzîhü'ş-şerîati'l-merfû'a ani'l-ahbâr'işşenîati'l-mevzû'a, thk. Abdulvehhab Abdullatîf - Abdullah Muhammed es-Sıddîk el-Gumârî (Beyrut: Dâru'lkütübi'l-ilmiyye, 1399), 1/298.

110 bk. Ebü'l-Ferec Cemâlüddîn Abdurrahman b. Ali b. Muhammed el-Cevzî, el-ilelü'l-mütenâhiye fi'l-ehâdîsi'lvâhiye, thk. İrşâdü'l-hakk el-Eserî 2 Cilt. (Faysalabâd: İdâratü'l-Ulûmi'l-eseriyye, 1401/1981), 1/107; Muhammed Tâhir b. Ali es-Sıddîkî el-Hindî el-Fettenî, Tezkiratü'l-mevzû'ât, (b.y.: İâratü't-Tıbâ'ati'l-Münîriyye, 1343), 77. 
Gaylân $>^{111}$ Ebû Dâvûd et-Tayâlisî > ${ }^{112}$ Şu'be $e^{113}$ ve Hişâm ${ }^{114}>$ Katâde ${ }^{115}>$ Zürâra b. Evfân ${ }^{116}>$ Sa'd b. Hişâm ${ }^{117}>$ Âişe. ${ }^{118}$

Rivayetin bu senedi Tirmizî'den Hz. Âişe'ye kadar hep sika râvilerden oluşmaktadır. Bu yönüyle en sağlam sened olduğunu söylemek mümkün olmakla beraber hem temel hadis kaynaklarında yer almaması açısından hem de Sehâvî'den Tirmizî'ye kadar olan râviler birincil hadîs râvilerinden olmadığı için bu senedin varlığı rivayetin sıhhati için kanaatimizce yeterli değildir.

Sonuç olarak mezkûr rivayetle ilgili ele alınıp incelenen senedlerden hiçbirinin tek başına rivayeti sıhhat derecesine çıkaramayacağı anlaşılmaktadır. Ancak birbirini destekledikleri için hasen li gayrihi olduğunu söylemek mümkündür. Araştırmada ele alınacak olan diğer mesele hâfızlığın unutulmasının vebalinin ne olduğudur. Bu vesileyle aşağıda bu konu hakkında vârid olan bazı rivayetler yine sened ve metin tenkidi üzerinden kısaca ele alınıp değerlendirilecektir.

\section{Hâfızlığın Unutulmasının Vebali}

Buhârî, Müslim ve başkalarının rivayet ettiği bir hadiste Hz. Peygamber (s.a.v.) Kur'an'dan bazı âyetleri unutan kişilerle ilgili şöyle bir uyarıda bulunmaktadır: "Onlardan birinin şu âyetleri unuttum demesi ne kötüdür! Bilakis ona unutturulmuştur. Kur'an'ı anımsayın! Zira o, develerin iplerinden sıyrılmasından daha hızlı bir şekilde kişilerin kalplerinden sıyrılıp ayrılır."119 Bu rivayette kişinin Kur'an'dan ezberlediklerini unuttuğunu söylemesinin Kur'an'a hürmet gibi muhtelif hikmetlerden ötürü ${ }^{120} \mathrm{~Hz}$. Peygamber (s.a.v.) tarafından kınandığı görülmektedir. Ancak bunun bir cezasından yahut büyük bir günah oluşundan söz edilmemiştir. Kanaatimizce sadece edebî bir üslûpla teşbîh sanatı kullanılarak Kur'an'ın sürekli olarak okunmasına teşvik söz konusudur.

Kur'an'ın tamamını veya bazı sûrelerini ezberledikten sonra unutmanın vebaline ve büyük günahlardan biri olduğuna dâir ise İbn Hacer'in de ifade ettiği

111 Sika bir râvi oluşu hakkında bk. Ebü'l-Hasan Ali b. Ebi'l-Kerem Muhammed b. Muahmmed İzzüddîn İbnü'lEsîr eş-Şeybânî el-Cezerî, el-Kâmil fi't-Târîh, thk. Ömer Abdüsselâm Tedmürî (Beyrut: Dâru'l-Kitâbi'l-Arabî, 1417/1997), 6/146; Ebû Abdillah Şemsüddîn Muhammed b. Ahmed b. Osmân b. Kaymâz ez-Zehebî, el-iber fî Haberi Men Ğaber, thk. Ebû Hâcer Muhammed es-Saîd b. Besyûnî Zağlûl (Beyrut: Dâru'l-Kütübi'l-IImiyye, ts.), $1 / 338$.

112 Sika bir râvi ve hadiste "Emîru'l-mü'minîn" vasfına sahip oluşu hakkında bk. Zehebî, el-iber fí Haberi Men Ğaber, $1 / 170$.

113 Hadis imamlarının büyüklerinden oluşu hakkında örnek olarak bk. Zehebî, Târîhu'l-Islâm, 9/416.

114 Hadis imamlarının büyüklerinden oluşu hakkında örnek olarak bk. Mizzî, Tehzîbü'l-Kemâl, 30/232.

115 Meşhur sika âlimlerlen olduğuna dair örnek olarak bk. Mizzî, Tehzîbü'l-Kemâl, 23/498.

116 Sika bir râvi oluşu hakkında örnek olarak bk. Mizzî, Tehzîbü'l-Kemâl, 9/339.

117 Enes b. Mâlik'in amcasının oğlu olan bu zatın meşhur sika tâbiîn râvilerinden biri olduğuna dair örnek olarak bk. Mizzî, Tehzîbü'l-Kemâl, 10/307.

118 bk. Sehâvî, Cemâlü'l-Kurrâ ve kemâlü'l-ikrâ, 181.

119 Buhârî, “Fedâilü'l-Kurân", 23; Müslim, "Fedâilü'l-Kurân”, 228; Tirmizî,, Kırâât", 8; Nesâî, "iftitâh", 37.

120 Bunlar için bk. Ebû Muhammed Bedruddîn Mahmûd b. Ahmed b. Musâ b. Ahmed b. el-Hüseyin el-Ayıntâbî elAynî, Umdetü'l-Kârî Şerhu Sahîhi'l-Buhârî (Beyrut: Dâru İhyâi't-Türâsi'l-Arabî, ts.), 20/47. 
gibi'21 âlimler arasında intilaf söz konusudur. Çoğunluğu ilgili bazı rivayetlerden ötürü bu görüşte olmakla beraber bazıları hem o rivayetlerin zayıf olduğunu hem de unutulmamasına teşvik amacıyla mübalağa içerdiğini ileri sürerek bunun büyük günahlardan olmadığını söylemişlerdir. ${ }^{122}$ Araştırmanın bu başlığı altında da bu rivayetlerden tespit edilen bazıları ele alınıp sened ve metin açısından değerlendirilecektir.

\subsection{Enes b. Mâlik Rivayeti ve Tenkidi}

Ebû Dâvûd ve Tirmizî başta olmak üzere bazı muhaddislerin Abdulvehhab b. Abdulhakem el-Hazzâz > Abdulmecîd b. Abdulazîz b. Ebû Ravvâd > İbn Cüreyc $>$ Muttalib b. Abdullah b. Hantab kanalıyla Enes b. Mâlik'ten rivayet ettiği bir hadiste Hz. Peygamber (s.a.v.) şöyle buyurmaktadır: "Kişinin mescitten çıkarttığı bir çöp tozuna varıncaya dek ümmetimin ecirleri/sevapları bana arz edildi. Aynı şekilde ümmetimin günahları da bana arz edildi. İçlerinde kişinin kendisine Kur'an'dan verilen bir sûreyi yahut bir ayeti unutmasından daha büyük bir günah görmedim."'23

Rivayetin sened tenkidi açısından öncelikle Tirmizî'nin şu değerlendirmesini aktarmak yerinde olacaktır: "Bu ğarîb bir hadistir. Bunu sadece bu tarikiyle biliyoruz. Muhammed b. İsmail'le bu rivayeti müzakere ettim. $\mathrm{O}$ bu hadisi tanımayıp garip buldu ve senedde tâbîi râvi olarak yer alan Müttalib b. Abdullah b. Hantab'ın 'Peygamber'in (s.a.v.) hutbesine şâhit olan biri bana anlattı' sözü hariç Hz. Peygamber'in (s.a.v.) ashâbının hiçbirinden semâ'ının olmadığını dile getirdi. Ayrıca Abdullah b. Abdurrahmân, 'Ali b. el-Medînî, Muttalib'in Enes'ten işittiğini inkâr etti.' demiştir. "124 Dolayısıyla rivayetin bu tarîkinde bir inkıtâ yahut tedlîs bulunmaktadır. Kurtubî de (ö. 671/1273) bundan yola çıkarak hadisin sâbit olmadığını dile getirmiştir. ${ }^{125}$ Ancak Abdulkâdir el-Arnâût bu konuda varid olan başka rivayetleri de göz önüne alarak, "Fakat hadisin kendisini hasen derecesine yükselten manaca şâhitleri bulunmaktadır." Ifadesini kullanmıştır. İbn Huzeyme'nin bu rivayeti Sahîh'ine almasının nedeni bu olsa gerektir. ${ }^{126}$

Ebû Dâvûd (ö. 275/889) ise rivayeti serdetmekle yetinip herhangi bir değerlendirme yapmamıştır. ${ }^{127}$ Taberânî'ye gelince iki tarîkinin birincisinde el-Muttalib'in yerinde Zührî; Abdulvehhab'ın yerinde Muhammed b. Yezîd elÂdemî bulunmaktadır. Buna göre senedde bir inkıtâ söz konusu değildir. Ancak

121 Ebü'I-Fadl Ahmed b. Ali b. Hacer el-Askalânî, Fethu'I-Bârîşerhu Sahîhi'l-Buhârî, thk. Muhammed Fuâd Abdulbâkî (Beyrut: Dâru'l-Ma'rife, 1379), 9/86.

122 Muhammed b. Ali b. Muhammed b. Abdullah eş-Şevkânî el-Yemenî, Neylü'l-Evtâr, thk. I'sâmüddîn es-Sabâbitî (Mısır: Dâru'l-Hadis, 1413/1993), 2/178.

123 Ebû Dâvûd, "Salât", 16; Tirmizî, "Fedâilü'l-Kurân”, 19; Ebû Bekr Muhammed b. İshak İbn Huzeyme en-Neysâbûrî, Sahîh, thk. Muhammed Mustafa el-Azamî (Beyrut: el-Mektebü'l-islâmî, ts.), 2/271; Beyhakî, es-Sünenü'l-kübrâ, $2 / 618$.

124 bk. Tirmizî, “Fedâilü'l-Kurân", 19.

125 Ebü'l-Feyz Ahmed b. Muhammed b. es-Sıddîk b. Ahmed el-Ğumârî el-Hasenî el-Ezherî, el-Müdâvî li Illeli'l-Câmi'i'sSağîr ve Şerhayi'l-Münâvî (Kahire: Dâru'I-Kütbâ, 1996), 4/448.

126 Ebû Zekeriyyâ Muhyiddîn Yahyâ b. Şeref en-Nevevî, el-Ezkâr, thk. Abdulkâdir el-Arnaût (Beyrut: Dâru'l-Fikr, 1414/1994), 1/106.

127 bk. Ebû Dâvûd, “Salât", 16. 
o Muhammed b. Yezîd'in bu rivayetle teferrüd ettiğini söylemiştir. İkinci tarîkinde ise yine el-Muttalib yer almaktadır. ${ }^{128}$

Rivayetin senedindeki râvilerden Muttalib b. Abdullah b. Hantab'ın tevsikinde münekkidler arasında ihtilaf söz konusudur. el-Muttalib'i tevsik edenler arasında İbn Hibbân, ${ }^{129}$ Ebû Zür'a ve Dârekutnî (ö. 385/995) yer almaktadır. ${ }^{130}$ Ebû Hâtim onunla ilgili, "Âiş̧e'ye yetişmedi. Hadislerinin çoğu mürseldir." demekle beraber ${ }^{131}$ Ebû Zür'a, "Âişe'den işitmiş olduğunu umuyorum."söylemiştir. ${ }^{132}$ İbn Sa'd da (ö. 230/845) onun hakkında "Hadisiyle ihticâc edilmez. Zira o çokça irsâl yapanlardandır." şeklinde eleştiride bulunmuştur. ${ }^{133}$

Münâvî́nin naklettiğine göre rivayetle ilgili İbn Hacer, "İsnâdında zayıflık olmakla beraber şâhitleri vardır."; Irâkî ise "Buhârî bu rivayeti ğarîb bulmuştur. Ancak Ebû Dâvûd sükût etmiştir." şeklinde değerlendirmede bulunmuşlardır. ${ }^{134}$

Rivayetle ilgili detaylı bir değerlendirme yapan Elbânî özetle şunları söylemiştir: "Ricâli tevsik edilmiş olsa da bu rivayetin isnâdı zayıftır. Zira iki yerinde inkıtâ vardır. Birincisi İbn Cüreyc ile el-Muttalib arasındadır. İkincisi de el-Muttalib ile Enes arasındadır."135

İbn Ebî Şeybe'nin Vekî > İbrahim b. Yezîd > Velîd b. Abdullah b. Ebû Muğîs kanalıyla naklettiği benzer bir rivayetin metni ise şu şekildedir: "Günahlar bana arz edildi. lçlerinde Kur'an'ı yüklenip de terk edenin günahından daha büyük bir şey görmedim." ${ }^{\prime 136}$ Tebei tâbiînden olan Velîd b. Abdullah sika bir râvi olsa da ${ }^{137}$ rivayet maktû bir hadistir. İbn Hacer, İbn Ebû Dâvûd'un da (ö. 316/929) bu rivayeti mürsel olarak naklettiğini ifade etmektedir. ${ }^{138}$

Ahmed b. Hanbel'in ez-Zühd adlı hadis cü'zünde Zeyd b. el-Habbâb > Hâlid b. Dînâr kanalıyla kaydettiği bir rivayette tâbiînden Ebü'l-Âliye de aynı meâlde şunu ifade etmektedir: "Kişinin Kur'an'ı öğrendikten sonra unutuncaya dek onu ihmal etmesini en büyük günahlardan sayardık."139 Kur'an'ı unutmanın en büyük musibetlerden biri olduğunu dile getiren İbn Hacer bu rivayetin isnâdının ceyyid olduğunu ifade etmektedir. Ayrıca İbn Sîrîn'in sahih bir isnadla Kur'an'ı unutan kişi hakkında "Bu insanı kerih görürlerdi ve onun hakkında ağır sözler konuşurlardı."

\footnotetext{
128 bk. Taberânî, el-Mu'cemu'l-evsat, 6/308.

129 İbn Hibbân, es-Sikât, 5/450.

130 Zehebî, Târîhu'l-Islâm, 7/471.

131 Zehebî, Târîhu'l-Islâm, 7/471.

132 İbn Ebû Hâtim, el-Cerh ve't-Ta'dîl, 8/359; Zehebî, Târîhu'l-Islâm, 7/471.

133 Zehebî, Târîhu'l-İslâm, 7/471.

134 Münâvî, Feyzü'I-Kadîr Şerhu'l-Câmi'i's-sağîr, 4/313.

135 Ebû Abdirrahmân Muhammed Nâsıruddîn el-Elbânî, Daîfu Ebî Dâvûd (Kuveyt: Müessesetü Ğırâs, 1423), 1/164.

136 İbn Ebî Şeybe, el-Musannef, 6/124.

137 İbn Ebû Hâtim, el-Cerh ve't-Ta'dîl, 9/9; Mizzî, Tehzîbü'I-Kemâl, 31/37; Zehebî, el-Kâşif, 2/352.

138 Ibn Hacer, Fethu'l-Bârî, 9/86.

139 Ebû Abdillah Ahmed b. Muhammed b. Hanbel b. Hilâl b. Esed eş-Şeybânî, ez-Zühd, thk. Muhammed Abdüsselâm Şâhîn (Beyrut: Dâru'I-Kütübi'I-IIlmiyye, 1420/1999), 245.
} 
dediğini kaydetmektedir. ${ }^{140}$ Sonuç olarak aynı meâldeki bu rivayetlerin desteğini alarak Tirmizî rivayetinin hasen li gayrihi olduğunu söylemek mümkündür.

\subsection{Sa'd b. Ubâde Rivayeti ve Tenkidi}

Ebû Dâvûd'un “Kur'an'ı Ezberleyip de Daha Sonra Unutan Kişinin Vahim Durumu" başlığı altında Sa'd b. Ubâde'den Muhammed b. el-Alâ > İbn İdrîs > Yezîd b. Ebû Ziyâd > İsâ b. Fâid kanalıyla rivayet ettiği bir hadiste Hz. Peygamber (s.a.v.) şöyle buyurmaktadır: "Kişi Kur'an'ı okur da sonra unutursa Allah'la (c.c.) kötürüm/eli kesik olarak karşılaşır."141 Ahmed b. Hanbel'in kaydettiği metin ise "... Kişi Kur'an'ı öğrenir de sonra unutursa.." şeklinde devam etmektedir. ${ }^{142}$

Rivayetin senedinde yer alan râvilerden ikisi problemlidir. Birincisi olan Yezîd b. Ebû Ziyâd'la ilgili İbn Maîn, "Hadisi zayıftır."143; İbn Hibbân, "Yaşlanınca hıfzı kötüleşti. Başkası tarafından kendisine telkin ediliyordu. İlk başlarda ondan hadis işitenlerin semâı sahihtir."144 ifadelerini kullanmışlardır. Ahmed b. Hanbel'e sorulduğunda da başını yana sallayıp zayıf olduğuna işaret etmiştir. ${ }^{145}$ Yine onun hakkında İbn Maîn, "Kavî değildir. Hadisiyle ihticâc edilmez."; ; ${ }^{146}$ İbnü'l-Mübârek de "At onu!" şeklinde tenkitte bulunmuşlardır. ${ }^{147}$

Meşhur biyografi yazarı İbn Sa'd da onunla ilgili şu ifadeleri kullanmıştır: "Haddi zatında sika bir insan idi. Ancak ömrünün sonunda hâfızası zayıflayınca acâyip şeyler dile getirmeye başladı." ${ }^{148}$ Benzer şekilde İclî de şunu söylemiştir: "Hadisi câiz olup sikadır. Ömrünün sonunda kendisine telkin ediliyordu." ${ }^{149}$ Aynı şekilde İbn Şâhin (ö. 385/996), Ahmed b. Sâlih'in (ö. 248/862) onun için, "O sikadır. Hakkında olumsuz konuşanların sözlerini beğenmiyorum." dediğini nakletmiştir. ${ }^{150}$

İkinci problemli râvi olan İsâ b. Fâid'le ilgili Buhârî'nin naklettiğine göre İbn Fudayl (ö. 195/811), "Rakka'nın emiri olan bu kişi irsâl yapan bir râvidir."151; İbnü'I-Medînî (ö. 234/848), “Ondan Yezîd b. Ebû Ziyâd'dan başkası rivayette

\footnotetext{
140 İbn Hacer, Fethu'I-Bârî, 9/86.

141 Ebû Dâvûd, "Vitir", 21.

142 Ahmed b. Hanbel, el-Müsned, 5/323.

143 İbn Adiyy, el-Kâmil fî Du'afâi'r-Ricâl, 9/163.

144 İbn Hibbân, el-Mecrûhîn, 3/99.

145 Zehebî, Târîhu'l-İsâm, 8/564.

146 İbn Maîn, Târîhu Ibn Maîn, 4/59.

147 Ebü'l-Fellâh Abdulhayy b. Ahmed b. Muhammed b. el-İmâd el-Akrî el-Hanbelî, Şezerâtü'z-zeheb fî Ahbâri Men Zeheb, thk. Mahmûd el-Arnaût (Dımaşk: Dâru İbn Kesîr, 1406/1986), 2/184.

148 Ebû Abdillah Muhammed b. Sa'd b. Menî' el-Hâşimî el-Basrî el-Bağdâdî, et-Tabakâtü'l-Kübrâ, thk. Muhammed Abdulkâdir Atâ (Beyrut: Dâru'l-Kütübi'I-IImiyye, 1410/1990), 6/330.

149 Ebü'l-Hasan Ahmed b. Abdullah b. Sâlih el-i̇clî el-Kûfî, Ma'rifetü's-Sikât, thk. Abdulalîm Abdulazîm el-Bestevî (Medine: Mektebetü'd-Dâr, 1405/1985), 2/364.

150 Ebû Hafs Ömer b. Ahmed b. Osmân İbn Şâhîn el-Bağdâdî, Târîhu Esmâi's-Sikât, thk. Subhî es-Sâmerrâî (Kuveyt: ed-Dâru's-Selefiyye, 1404/1984), 1/256.

151 Buhârî, et-Târîhu'l-Kebîr, 6/386.
} 
bulunmamıştır."; İbn Abdülber (ö. 463/1071), "Bu isnâd bu konuda rivayet edilen en güzel isnaddır. Ancak İsa b. Fâid Sa'd b. Ubâde'den hadis işitmemiştir. Zira ona yetişmemiştir. Ondan Yezîd b. Ebû Ziyâd'dan başkasının rivayette bulunduğunu da sanmam."152 İfadelerini kullanmışlardır. Ayrıca İbnü'l-Medînî İsâ b. Fâid'in mechûl bir râvi olduğunu dile getirmiş̧tir. ${ }^{153}$

Elbânî rivayetin senedinin üç illetten ötürü zayıf olduğunu söylemiştir. Birincisi, İsa b. Fâid ile İbn Ubâde arasındaki inkıtâdır. Zira ona yetişmemiştir. İkincisi, İsa b. Fâid'in mechûl oluşudur. Üçüncüsü de, Yezîd b. Ebû Ziyâd'ın münekkidlerin çoğuna göre zayıf olmasıdır. ${ }^{154}$ İbn Hacer de bu rivayetin isnâdında sorun olduğunu dile getirmiştir. ${ }^{155}$ Dolayısıyla bu rivayetin hem zikredilen nedenlerden ötürü hem de ona mütâbi' olabilecek nitelikte başka rivayetlerin bulunmayışından yola çıkarak itibar edilemeyecek düzeyde aşırı zayıf olduğunu söylemek mümkündür.

\section{Sonuç}

Çalışmanın iki konusundan biri olan Kur'an hâfızlarının âhirette şefaat hakkı konusunda ilgili rivayetler üzerinden yapılan araştırmalar neticesinde şu sonuçlara varılmıştır. Öncelikle Kur'an'ın bizzat kendisinin şefaatte bulunacağına dair birtakım sahih rivayetler olduğu görülmüştür. Allah'ın (c.c.) şefaatte bulunma yetkisi verdiği kişiler içerisinde peygamberler ve şehitlerin yanı sıra belli şartları taşıyan Kur'an hâfızlarının da bulunduğu anlaşılmıştır. Kur'an hâfızlarının, yakınlarından on kişiye yahut sayısı net olmayan bir gruba şefaat edebileceğine dair üç sahâbîkanalıyla nakledilen bir rivayet tespit edilmiştir. Bu rivayetin muhtelif senedlerinin her biri müstakil olarak zayıf olsa da birbirlerini destekledikleri için ilgili rivayetin hasen li gayrihi derecesine yükseldiğini söylemek mümkündür.

Kur'an hâfızlarınınyetmiş kişiye şefaat edeceklerine dair ise hadis kaynaklarında herhangi bir rivayete rastlanılmamıştır. Bazı rivayetlere göre bu sayıda kişiye şefaat etme hakkı Kur'an hâfızları için değil şehitler için söz konusudur. Ayrıca âlimlerin de şefaat edecek gruplardan biri olduğuna dair nakledilen rivayetin ya uydurma ya da en azından itibar edilemeyecek düzeyde aşırı zayıf olduğu görülmüştür. Ancak bu durumdan hiçbir âlimin şefaatçi olamayacağı sonucu çıkarılmamalıdır. Zira Kur'an ve Sünnet'te genel anlamda zikredilen şefaatçilerin içerisinde birtakım âlimlerin bulunması gayet normaldir.

Çalışmanın ikinci konusu olan hâfızlığın unutulmasının vebaliyle ilgili incelenen iki rivayetten Kur'an'ın tamamını veya bir kısmını unutmanın büyük günahlardan biri olduğunu ifade eden birinci rivayetin bazı mütâbi'lerinden ötürü hasen li gayrihi olduğu tespit edilmiştir. Nitekim çağdaş hadisçilerden Abdulkâdir el-Arnâût da daha önce ifade edildiği gibi bu kanaattedir. Kur'an'ı

152 Mizzî, Tehzî́bü'l-Kemâl, 23/21.

153 İbn Hacer, Tehzîbü't-Tehzîb, 8/227.

154 Elbânî, Dâîfu Ebî Dâvûd, 2/86.

155 İbn Hacer, Fethu'l-Bârî, 9/86. 
unutan kişinin âhirette kötürüm yahut eli kesik olarak Allah'ın (c.c.) karşısına çıkacağına dair nakledilen ikinci rivayetin ise itibar edilemeyecek düzeyde aşırı zayıf olduğu anlaşılmıştır.

Sonuç olarak bu araştırmada Kur'an hâfızlığı konusunda terğîb yahut terhîb amacıyla bile olsa mevzû yahut ihticâc ve itibar edilemeyecek düzeyde aşırı zayıf olan rivayetlerin insanlara hadis olarak aktarılmaması gerektiği ortaya çıkmıştır. 


\section{Kaynakça}

Âcurrî, Ebû Bekir Muhammed b. el-Hüseyin b. Abdillah el-Bağdâdî el-. eş-Şerî̀a. thk. Abdullah b. Ömer b. Süleyman ed-Dümeycî. 5 Cilt. Riyad: Dâru'I-Vatan, 1420/1999.

Ahmed b. Hanbel, Ebû Abdillah Ahmed b. Muhammed b. Hanbel b. Hilâl b. Esed eşŞeybânî. Müsned. 6 Cilt. İstanbul: Çağrı Yayınları, 1413/1992.

Ahmed b. Hanbel, Ebû Abdillah Ahmed b. Muhammed b. Hanbel b. Hilâl b. Esed eşŞeybânî. ez-Zühd. thk. Muhammed Abdüsselâm Şâhîn. Beyrut: Dâru'I-Kütübi'l-IImiyye, 1420/1999.

Aydemir, Abdullah. "Fezâilü'l-Kur'ân". Türkiye Diyanet Vakfı İslâm Ansiklopedisi. 12/532534. İstanbul: TDV Yayınları, 1995.

Aynî, Ebû Muhammed Bedruddîn Mahmûd b. Ahmed b. Musâ b. Ahmed b. el-Hüseyin el-Ayıntâbî el-. Umdetü'l-Kârî Şerhu Sahîhi'I-Buhârî. 25 Cilt. Beyrut: Dâru Ihyâii't-Türâsi'lArabî, ts.

Beyhakî, Ebû Bekir Ahmed b. Hüseyin b. Ali b. Musa el-Horasânî. es-Sünenü'l-kübrâ. thk. Muhammed Abdulkâdir Atâ. 10 Cilt. Beyrut: Dâru'I-Kütübi'I-Ilmiyye, 1424/2003.

Beyhakî, Ebû Bekir Ahmed b. el-Hüseyin b. Ali b. Musa el-Horasânî el. Şu'abu'l-îmân. thk. Abdülalî Abdülhamîd Hâmid. 14 Cilt. Riyad: Mektebetü'r-Rüşd, 1423/2003.

Bezzâr, Ebû Bekir Ahmed b. Amr b. Abdilhâlik b. Hallâd b. Ubeydillah el-Atekî el-. el-Müsned: el-Bahru'z-zehhâr. thk. Mahfûzurrahmân Zeynüllah vd. 18 Cilt. Medine: Mektebetü'lulûm ve'l-hikem, 1988/2009.

Bozkurt, Nebi. "Hâfız". Türkiye Diyanet Vakfı İslâm Ansiklopedisi. 15/74-78. İstanbul: TDV Yayınları, 1997.

Buhârî, Ebû Abdillah Muhammed b. İsmail b. İbrahim b. el-Muğîra el-. ed-Duafâü's-sağîr. thk. Ebû Abdillah Ahmed b. İbrâhim b. Ebi'l-Ayneyn. b.y: Mektebetü İbn Abbâs, $1426 / 2005$.

Buhârî, Ebû Abdillah Muhammed b. İsmail b. İbrahim b. el-Muğîra el-. et-Târîhu'l-evsat. thk. Mahmûd İbrahim Zâyid. 2 Cilt. Halep: Dâru'I-Va'y, 1397/1977.

Buhârî, Ebû Abdillah Muhammed b. İsmail b. İbrahim b. el-Muğîra el-. et-Târîhu'l-kebîr. 8 Cilt. Haydarabâd: Dâiratü'l-Ma'ârifi'l-Osmâniyye, ts.

Bûsırî, Ebü'l-Abbâs Şihâbüddîn Ahmed b. Ebî Bekir b. İsmail b. Selîm b. Kaymaz b. Osman el-Kinânî el-. İthâfü'l-hîrati'I-mehera bi zevâidi'l-mesânîdi'l-aşere. thk. Ebû Temîm Yâsir b. İbrâhim. 9 Cilt. Riyad: Dâru'I-Vatan, 1420/1999.

Bûsırî, Ebü'l-Abbâs Şihâbüddîn Ahmed b. Ebî Bekir b. İsmail b. Selîm b. Kaymaz b. Osman el-Kinânî el-. Misbâhu'z-zücâce fî zevâidi İon Mâce. thk. Muhammed el-Müntekâ elKüşnâvî. 4 Cilt. Beyrut: Dâru'l-Arabiyye, 1403.

Cevzecânî, Ebû İshak İbrâhim b. Yakûb b. İshak es-Sa'dî el-. Ahvâlü'r-ricâl. thk. Abdülalîm Abdülazîm el-Bestevî. Faysalabâd: Hadis Akademi, ts.

Çakır, Mesut. Fezâilü'l-Kur'an Hadisleri Çerçevesinde Kur'an'ın Ezberlenmesi ile IIlgili Rivayetlerin Tahrîc ve Değerlendirilmesi. İstanbul: Marmara Üniversitesi, Sosyal Bilimler Enstitüsü, 2007. 
Çakır, Mesut vd. "Hâfızlığı Teşvik Eden Hadisler Üzerine Genel Bir Değerlendirme". Kafkas Üniversitesi Illahiyat Fakültesi Dergisi 5/9 (2018), 118-140.

Çelik, Hüseyin. "Kur'an'da Şefaat". Tokat IIImiyat Dergisi 3/1 (Ocak 2015), 283-313.

Dağ, Ökkeş. Hz. Peygamber Zamanında Kur'an'ın Ezberlenmesi ve Hâfız Sahabiler. Ankara: Ankara Üniversitesi, Sosyal Bilimler Enstitüsü, Yüksek Lisans Tezi, 2006.

Ebû Dâvûd, Süleyman b. Eş'as. Sünenü Ebî Dâvûd. 5 Cilt. İstanbul: Çağrı Yayınları, 1413/1992.

Elbânî, Ebû Abdirrahmân Muhammed Nâsıruddîn el-. Daîfu Ebî Dâvûd. 2 Cilt. Kuveyt: Müessesetü Ğırâs, 1423.

Elbânî, Ebû Abdirrahmân Muhammed Nâsıruddîn el-. Sahîhu Ebî Dâvûd. 7 Cilt. Beyrut: Müessesetü Gırâs li'n-Neşr ve't-Tevzî', 1423/2002.

Elbânî, Ebû Abdirrahmân Muhammed Nâsıruddîn b. el-Hâc Nuh b. Necâtî b. Âdem el-. Silsiletü'l-ehâdisi'd-daîfe ve'l-mevzû'a. 14. Cilt. Riyad: Dâru'l-Ma'ârif, 1412/1992.

Fesevî, Ebû Yusuf Yakûb b. Süfyân b. Civân el-Fârisî el-. el-Ma'rife ve't-târîh. thk. Ekrem Dıyâ el-Ömerî. 3 Cilt. Beyrut: Müessesetü'r-Risâle, 1401/1981.

Fettenî, Muhammed Tâhir b. Ali es-Sıddîkî el-Hindî el-. Tezkiratü'I-mevzû'ât. b.y.: İâratü'tTıbâ'ati'l-Münîriyye, 1343

Firyâbî, Ebû Bekr Ca'fer b. Muhammed b. el-Hasan b. el-Müstefâd el-. Fedâilü'l-Kur'ân. thk. Yusuf Osman Fadlüllah Cibrîl Riyad: Mektebetü'r-Rüşd, 1409/1989.

Ğumârî, Ebü'l-Feyz Ahmed b. Muhammed b. es-Sıddîk b. Ahmed el-Hasenî el-Ezherî el-. el-Müdâvî li Illeli'l-Câmi'i's-Sağîr ve Şerhayi'l-Münâvî. 6 Cilt. Kahire: Dâru'I-Kütbâ, 1996.

Hatîb, Ebû Bekir Ahmed b. Ali b. Sâbit el-Bağdâdî. Târîhu Bağdâd ve Züyûlüh. 24 Cilt. Beyrut: Dâru'l-Kütübi'l-IImiyye, 1417.

Hemedânî, Ebû Abdirrahmân Mukbil b. Hâdî b. Mukbil b. Kâide el-Vâdi'î el-. eş-Şefâ'a. San'a: Dâru'l-Âsâr li'n-Neşr ve't-Tevzî', 1420/1999.

Herarî, Muhammed el-Emîn b. Abdillah el-Üramî el-Alevî eş-Şâfi'î el-. el-Kevkebü'l-vehhâc ve'r-ravzu'I-behhâc fi şerhi Sahîhi Müslim b. el-Haccâc. 26 Cilt. Mekke: Dâru'I-Minhâc, $1430 / 2009$.

Herevî, Ebû Ubeyd el-Kâsım b. Sellâm b. Abdillah el-Bağdâdî el-. Fedâilü'l-Kur'ân. thk. Mervân el-Atıyye vd. Dımaşk: Dâru İbn Kesîr, 1415/1995.

Heysemî, Ebü'l-Hasan Nûruddîn Ali b. Ebî Bekir b. Süleymân el-. Mecme'u'z-zevâid ve menbe'u'l-fevâid. thk. Husâmüddîn el-Kudüsî. 10 Cilt. Kahire: Mektebetü'l-Kudüsî, 1414/1994.

İbn Adiyy, Ebû Ahmed el-Cürcânî. el-Kâmil fî du'afâi'r-ricâl. thk. Âdil Ahmed Abdülmevcûd - Ali Muhammed Muavvaz. Beyrut: Dâru'I-Kütübi'l-IImiyye, 1418/1997.

İbn Arrâk, Nûruddîn Ali b. Muhammed b. Ali b. Abdurrahman el-Kinânî. Tenzîhü'ş-şerîati'lmerfû'a ani'l-ahbâr'iş-şenîati'l-mevzû'a. thk. Abdulvehhab Abdullatîf - Abdullah Muhammed es-Sıddîk el-Gumârî. 2 Cilt. Beyrut: Dâru'l-kütübi'l-ilmiyye, 1399.

İbn Asâkir, Ebü'l-Kâsım Ali b. Hasan b. Hibetillah. Târîhu Dımaşk. thk. Amr b. Garâme elAmrî. 80 Cilt. Beyrut: Dâru'l-Fikr, 1415/1995.

İbn Atıyye, Ebû Muhammed Abdülhak b. Şâlib b. Abdirrahmân el-Endelüsî el-Muhâribî. elMuharraru'l-vecîz fî tefsîri'l-Kitâbi'l-azîz. thk. Abdusselâm Abduşşâfî Muhammed 6 Cilt. Beyrut: Dâru'I-Kütübi'l-IIImiyye, 1422. 
İbn Ebû Hâtim, Ebû Muhammed Abdurrahman b. Muhammed b. İdris b. el-Münzir et-Temîmî el-Hanzalî er-Râzî. el-Cerh ve't-ta'dîl. Haydarabâd: Dâiratü'l-Ma'ârifi'lOsmâniyye, 1371/1952.

İbn Hacer, Ebü'l-Fadl Ahmed b. Ali el-Askalânî. Fethu'l-Bârî Şerhu Sahîhi'l-Buhârî. thk. Muhammed Fuâd Abdulbâkî. 13 Cilt. Beyrut: Dâru'I-Ma'rife, 1379.

İbn Hacer, Ebü'l-Fadl Ahmed b. Ali b. Muhammed b. Ahmed el-Askalânî. Tehzîbü't-Tehzîb. 12 Cilt. Hindistan: Matba'atü Dâirati'l-Ma'ârifi'n-Nizâmiyye, 1326.

İbn Hibbân, Ebû Hâtim Muhammed b. Hibbân b. Ahmed b. Hibbân b. Muâz b. Ma'bed et-Temîmî el-Büstî ed-Dârimî. el-Mecrûhîn mine'l-muhaddisîn ve'd-duafâi ve'l-metrûkîn. thk. Mahmûd İbrâhim Zâyid. 3 Cilt. Halep: Dâru'I-Va'y, 1396.

İbn Hibbân, Ebû Hâtim Muhammed b. Hibbân b. Ahmed b. Hibbân b. Muâz b. Ma’bed etTemîmî ed-Dârimî el-Büstî. es-Sikât. 9 Cilt. Haydarabâd: Dâiratü'I-Ma'ârifi'I-Osmâniyye, $1393 / 1973$.

İbn Hibbân, Ebû Hâtim Muhammed b. Hibbân b. Ahmed ed-Dârimî el-Büstî. Sahîh. thk. Şuayb el-Arnavut. 18 Cilt. Beyrut: Müessesetü'r-Risâle, 1414/1993.

İbn Huzeyme, Ebû Bekr Muhammed b. İshak en-Neysâbûrî. Sahîh. thk. Muhammed Mustafa el-Azamî. 4 Cilt. Beyrut: el-Mektebü'l-islâmî, ts.

İbn Kutluboğa, Ebü'l-Fidâ Zeynüddîn Kasım b. Kutluboğa es-Sûdûnî el-Cemâlî el-Hanefî. es-Sikât mimmen lem yeka' fi'l-kütübi's-sitte. thk. Şâdî b. Muhammed b. Sâlim Âl-i Numân. 9 Cilt. San'â: Mektebetü'n-Numân, 1432/2011.

İbn Mâce, Ebû Abdillah Muhammed b. Yezîd. Sünenü Ibn Mâce. 2 Cilt. İstanbul: Çağrı Yayınları, 1413/1992.

İbn Maîn, Ebû Zekeriyya Yahya b. Maîn b. Avn b. Ziyâd b. Bestâm b. Abdurrahmân el-Mürrî el-Bağdâdî. Târihu Ibn Maîn. thk. Ahmed Muhammed Nûr Seyf. Dımaşk: Dâru'l-Me'mûn li't-Türâs, ts.

İbn Manzûr, Ebü'l-Fadl Cemâlüddîn Muhammed b. Mükerrem b. Ali er-Ruveyfiî̀ el-ifrîkî. Lisânü'l-Arab. 15 Cilt. Beyrut: Dâru Sâdir, 1414.

İbn Sa'd, Ebû Abdillah Muhammed b. Sa'd b. Menî' el-Hâşimî el-Basrî el-Bağdâdî. etTabakâtü'I-Kübrâ. thk. Muhammed Abdulkâdir Atâ. 8 Cilt. Beyrut: Dâru'I-Kütübi'lilmiyye, 1410/1990.

İbn Şâhîn, Ebû Hafs Ömer b. Ahmed b. Osman b. Ahmed b. Muhammed b. Eyyûb elBağdâdî. el-Mühtelef fîhim. thk. Abdurrahîm b. Muhammed b. Ahmed el-Kaşkarî. Riyad: Mektebetü'r-Rüşd, 1420/1999.

İbn Şâhîn, Ebû Hafs Ömer b. Ahmed b. Osman b. Ahmed el-Bağdâdî. et-Terğîb fî fezâili'l'amâl ve sevâbü zâlik. thk. Muhammed Hasan Muhammed Hasan İsmail. Beyrut: Dâru'lKütübi'l-ilmiyye, 1424/2004.

İbn Şâhîn, Ebû Hafs Ömer b. Ahmed b. Osmân el-Bağdâdî. Târîhu Esmâi's-Sikât. thk. Subhî es-Sâmerrâî. Kuveyt: ed-Dâru's-Selefiyye, 1404/1984.

İbnü'd-Düreys, Ebû Abdillah Muhammed b. Eyyûb b. Yahyâ el-Becelî er-Râzî. Fedâilü'lKur'ân. thk. Gazve Büdeyr Dımaşk: Dâru'l-Fikr, 1408/1987.

İbnü'l-Esîr, Ebü'l-Hasan Ali b. Ebi'l-Kerem Muhammed b. Muhammed İzzüddîn eş-Şeybânî el-Cezerî. el-Kâmil fi't-Târîh. thk. Ömer Abdüsselâm Tedmürî. 10 Cilt. Beyrut: Dâru'|- 
Kitâbi'l-Arabî, 1417/1997.

İbnü'l-Cevzî, Ebü'l-Ferec Cemâlüddîn Abdurrahman b. Ali b. Muhammed el-Cevzî. el-illelü'lmütenâhiye fi'l-ehâdîsi'l-vâhiye. thk. İrşâdü'I-hakk el-Eserî. 2 Cilt. Faysalabâd: İdâratü'lUlûmi'l-eseriyye, 1401/1981.

İbnü'l-Cevzî, Ebü'l-Ferec Cemâlüddîn Abdurrahmân b. Ali b. Muhammed el-Cevzî. etTahkîk fî ehâdîsi'I-hilâf. thk. Müs'id Abdülhamîd. 2 Cilt. Beyrut: Dâru'l-Kütübi'I-IImiyye, 1415.

İbnü'l-İmâd, Ebü'l-Fellâh Abdulhayy b. Ahmed b. Muhammed b. el-İmâd el-Akrî el-Hanbelî. Şezerâtü'z-zeheb fî Ahbâri Men Zeheb. thk. Mahmûd el-Arnaût. 11 Cilt. Dımaşk: Dâru İbn Kesîr, 1406/1986.

İbnü'l-Kattân, Ebü'l-Hasan Ali b. Muhammed b. Abdilmelik el-Kettâmî el-Himyerî el-Fâsî. Beyânü'l-vehm ve'l-îhâm fî Kitâbi'l-Ahkâm. thk. el-Hüseyin Âyet Saîd. 6 Cilt. Riyad: Dâru Taybe, 1418/1997.

İclî, Ebü'l-Hasan Ahmed b. Abdullah b. Sâlih el-Kûfî el-. Ma'rifetü's-Sikât. thk. Abdulalîm Abdulazîm el-Bestevî. Medine: Mektebetü'd-Dâr, 1405/1985.

İsfahânî, Ebü'l-Kâsım el-Hüseyn b. Muhammed er-Râgıb el-. el-Müfredât fî garîbi'I-Kur'an. thk. Safvân Adnân ed-Dâvîdî Dımaşk: Dâru'I-Kalem, 1412.

Irâkî, Ebü'l-Fadl Zeynüddîn Abdurrahîm b. el-Hüseyin b. Abdirrahmân el. Tahrîü ehâdîsi ihyâi ulûmiddîn. 7 Cilt. Riyad: Dâru'l-Âsıme li'n-Neşr, 1408/1987.

Kurtubî, Ebû Ömer Yusuf b. Abdillah b. Muhammed b. Abdilberr b. Âsım en-Nemerî el-. Câmi'u beyâni'l-ilm ve fazlih. thk. Ebü'l-Eşbâl ez-Züheyrî. 2 Cilt. Riyad: Dâru İbni'l-Cevzî, 1414/1994.

Mizzî, Ebü'l-Haccâc Cemâlüddîn Yusuf b. Abdurrahmân b. Yusuf el-Kelbî el-. Tehzîbü'lKemâl fi Esmâi'r-Ricâl. thk. Beşşâr Avvâd Ma'rûf. 35 Cilt. Beyrut: Müessesetü'r-Risâle, $1400 / 1980$.

Muhammedî, Ebû Zerr Abdülkâdir b. Mustafa b. Abdirrezzâk el-. eş-Şefâ'atü fi'l-hadisi'nnebevî. Beyrut: Daru'I-Kütübi'l-IIImiyye, 1426/2005.

Mübârekfûrî, Ebü'l-Hasan Ubeydullah b. Muhammed b. Abdisselâm er-Rahmânî el-. Mir'âtü'l-mefâtîh şerhu Mişkâti'I-mesâbîh 9 Cilt. Vârânasi: İâratü'l-Buhûsi'I-IImiyyeti ve'd-Da'veti ve'l-iftâ, 1404/1984.

Münâvî, Zeynüddîn Muhammed Abdurraûf b. Tâcilârifîn b. Ali b. Zeynilâbidîn el-Haddâdî, el-Kâhirî el-. et-Teysîr bi şerhi'l-Câmi'i's-sağîr. 2 Cilt. Riyâd: Mektebetü'I-İmâm eş-Şâfi'î, $1408 / 1998$.

Münâvî, Zeynüddîn Muhammed Abdurraûf b. Tâcilârifîn b. Ali b. Zeynilâbidîn el-Haddâdî el-Kâhirî el-. Feyzü'l-kadîr şerhu'I-Câmi'i's-sağîr. 6 Cilt. Mısır: el-Mektebetü't-Ticâriyyeti'lKübrâ, 1356.

Müslim, Ebü'l-Hüseyin Müslim b. el-Haccâc. Sahîhu Müslim. 3 Cilt. İstanbul: Çağrı Yayınları., $1413 / 1992$.

Nesâî, Ebû Abdirrahmân Ahmed b. Şuayb b. Ali el-Horasânî en-. Fedâilü'l-Kur'ân. thk. Fârûk Hammâde Beyrut: Dâru's-Sekâfe, 1413/1992.

Nevevî, Ebû Zekeriyyâ Muhyiddîn Yahyâ b. Şeref en-. el-Ezkâr. thk. Abdulkâdir el-Arnaût. Beyrut: Dâru'l-Fikr, 1414/1994. 
Özbek, Ömer. "Dünyada Hâfızlık Yöntem Örnekleri”. Bilimname 29/2 (2015), 183-209.

Sehâvî, Ebü'l-Hasan Alemüddîn Ali b. Muhammed b. Abdissamed el-Mısrî eş-Şâfiî elHemedânî es. Cemâlü'l-Kurrâ ve kemâlü'l-Ikrâ. thk. Mervân el-Atıyye - Muhsin Harâbe. Dımaşk: Dâru'I-Me'mûn li't-Türâs, 1418/1997.

Şahin, Hatice. "Başlangıcından Günümüze Kadar İslam Coğrafyasında Hâfızlık Tedrisatı". Dinbilimleri Akademik Araştırma Dergisi 11/2 (2011), 199-220.

Şevkânî, Muhammed b. Ali b. Muhammed b. Abdullah el-Yemenî eş-. Neylü'l-Evtâr. thk. I'sâmüddîn es-Sabâbitî. 8 Cilt. Mısır: Dâru'l-Hadis, 1413/1993.

Taberânî, Ebü'l-Kâsım Süleyman b. Ahmed b. Eyyüb el-Lahmî. el-Mu'cemu'l-evsat. thk. Târık b. Ivazıllah b. Muhammed-Abdulmuhsin b. İbrahim el-Hüseynî. 10 Cilt. Kahire: Dâru'IHaremeyn, ts."

Taberî, Ebû Ca'fer Muhammed b. Cerîr b. Yezîd et-. Câmi'u'l-beyân fî te'vîili'l-Kur'ân. thk. Ahmed Muhammed Şâkir 24 Cilt. Beyrut: Müessesetü'r-Risâle, 1420/2000.

Tirmizî, Ebû İsa Muhammed b. İsa b. Sevra. Sünenü't-Tirmizî. 5 Cilt. İstanbul: Çağrı Yayınları, 1413/1992.

Useymîn, Muhammed b. Sâlih b. Muhammed el-. Şerhu Riyâzi's-sâlihîn. 6 Cilt. Riyad: Dâru'lVatan li'n-Neşr, 1426.

Yılmaz, Mehmet. Kur'an'da Şefaat Kavramı ve Yaygın Şefaat Anlayışıyla Karşılaştııılması. İstanbul: Marmara Üniversitesi, Sosyal Bilimler Enstütüsü, Yüksek Lisans Tezi, İstanbul, 2006.

Zebîdî, Ebü'l-Feyz Muhammed b. Muhammed b. Abdirrezzâk el-Hüseynî Mürtezâ ez-. Tâcü'l-arûs min cevâhiri'l-kâmûs. 40 Cilt. Beyrut: Dâru'l-Hidâye, ts.

Zehebî, Ebû Abdillah Şemsüddîn Muhammed b. Ahmed b. Osman b. Kaymaz ez-. Dîvânü'd-duafâ ve'I-metrûkîn ve halkin mine'l-mechûlîn ve sikâtin fihim lîn. thk. Hammâd b. Muhammed el-Ensârî. Mekke: Mektebetü'n-Nahdati'l-Hadise, 1387/1967.

Zehebî, Ebû Abdillah Şemsüddîn Muhammed b. Ahmed b. Osmân b. Kaymâz ez-. el-iber fî Haberi Men Ğaber. thk. Ebû Hâcer Muhammed es-Saîd b. Besyûnî Zağlûl. 4 Cilt. Beyrut: Dâru'l-Kütübi'l-IIlmiyye, ts.

Zehebî, Ebû Abdillah Şemsüddîn Muhammed b. Ahmed b. Osman b. Kaymaz ez-. el-Kâşif fî ma'rifeti men lehü rivayetün fi'l-kütübi's-sitte. thk. Muhammed Avvâme - Ahmed Muhammed Nemir el-Hatîb. 2 Cilt. Cidde: Dâru'l-Kıble li's-Sekâfeti'l-i̇slâmiyye, $1413 / 1992$.

Zehebî, Ebû Abdillah Şemsüddîn Muhammed b. Ahmed b. Osman b. Kaymaz ez-. Issbâtü'şşefâ'a. thk. İbrâhim Bâcis Abdülmecîd. Nşr: Advâü's-Selef, 1420/2000.

Zehebî, Ebû Abdillah Şemsüddîn Muhammed b. Ahmed b. Osman b. Kaymaz ez-. Mîzânü'li'tidâl fî nakdi'r-ricâl. thk. Ali Muhammed el-Becâvî. 4 Cilt. Beyrut: Dâru'l-Ma'rife, 1382/1963.

Zehebî, Ebû Abdillah Şemsüddîn Muhammed b. Ahmed b. Osman b. Kaymaz. Siyeru 'alâmi'n-nübelâ. thk. Şuayb el-Arnaût. 25 Cilt. Beyrut: Müessesetü'r-Risâle, 1405/1985.

Zehebî, Ebû Abdillah Şemsüddîn Muhammed b. Ahmed b. Osman b. Kaymaz ez-. Târihu'lİslâm ve vefeyâtü'l-meşâhîri ve'l-'alâm. thk. Ömer Abdüsselâm et-Tedmürî. 52 Cilt. Beyrut: Dâru'I-Kitâbi'l-Arabî, 1413/1993. 
